\title{
A Visual Typology of Abandonment in Rural America: From End-of-Life to Treading Water, Recycling, Renaissance, and Revival
}

\author{
Jason P. Holcomb ${ }^{1}$, Paul Frederic ${ }^{2}$ and Stanley D. Brunn ${ }^{3, *}$ \\ 1 Department of Agricultural Sciences, Morehead State University, Morehead, KY 40351, USA; \\ j.holcomb@moreheadstate.edu \\ 2 Department of Geography and Environmental Planning, University of Maine at Farmington, \\ Farmington, ME 04938, USA; frederic@myfairpoint.net \\ 3 Department of Geography, University of Kentucky, Lexington, KY 40506, USA \\ * Correspondence: stan.brunn@uky.edu
}

Received: 28 January 2020; Accepted: 18 March 2020; Published: 23 March 2020

\begin{abstract}
The contemporary American rural landscape reflects a mix of ongoing economic changes in agricultural land use, population change, and built environments. The mix depends on past and recent change which represent landscapes of memory and silence to those experiencing economic and demographic renaissance. We develop a typology of five stages that reflect the contemporary rural scene and conduct field transects in Northwest Iowa and Central Maine. Features of the dynamics in rural America are evident in photographs of residences, land use changes, and commercial structure. The study calls for additional studies on rural settlement populations, economies, and society in different environmental settings.
\end{abstract}

Keywords: small town landscapes; rural devolution and evolution; abandonment and renaissance

"Beyond the romance of decay stands the hard facts of economic reality" [1]

"... the disappearance of rural services is a product of both overarching global social and economic processes, and national and regional factors" [2]

"Each human settlement has a life cycle in which there is sometimes an indication of sudden change and novelty" [3]

\section{Introduction}

Changes in rural America are much in evidence in small town landscapes across the U.S. Those changes are observed in population numbers, built environments, agricultural, mining, forestry, and fishing economies, and in the livelihoods of long-time residents. In some places the visible landscapes reflect abandonment and dereliction, while other places are experiencing some recycling and rebirth. A realistic perspective of rural America would reveal changes in agricultural, industrial, mining, and fishing economies that reflect a mix of diversity, not only "what was," but also "what is" occurring and "what might be" the future of those living and working in rural settlements in New England, the Middle West, and elsewhere.

How residents of rural America, and those in urban America, perceive the demographic and economic landscapes can be obtained from the titles of recent newspaper and magazine articles (Table 1). But the despair or gloom and doom so often the focus of these accounts is only partially true. Those who live, work, and travel through these rural and small-town landscapes attest that the realities are much different. There are places in the above regions and elsewhere that one might consider residents 
are living in deep despair, that is, prolonged population loss and closing of functions and institutions; however, there are other places in rural America that are experiencing some renewal and renaissance. Figure 1 represents one perspective on rural America today, viz., the places that are experiencing population losses. A closer examination of this pattern would reveal some places of long and sustained losses while for others the losses have been only in recent decades.

Table 1. Example newspaper and magazine article titles.

\begin{tabular}{cc}
\hline Title & Newspaper/Magazine \\
\hline $\begin{array}{c}\text { Turning the Bus Around: One Town's Story } \\
\text { Dollar General }\end{array}$ & $\begin{array}{c}\text { Maine Townsman: Magazine of the Maine } \\
\text { Municipal Association [4] }\end{array}$ \\
How South Dakota's small grocers are competing with & Argus Leader [5] \\
Dollar General's aggressive expansion into small & Milwaukee Journal Sentinel [6] \\
Wisconsin towns has hurt locally owned grocery stores & The Des Moines Register [7] \\
Held 'hostage' by Tyson: An Iowa town's dilemma & The Week [8] \\
The unconscionable abandonment of rural America & The Atlantic [9] \\
The Graying of Rural America & The Conversation [10] \\
Most of America's rural areas are doomed to decline & The Atlantic [11] \\
What America Is Losing as Its Small Towns Struggle &
\end{tabular}

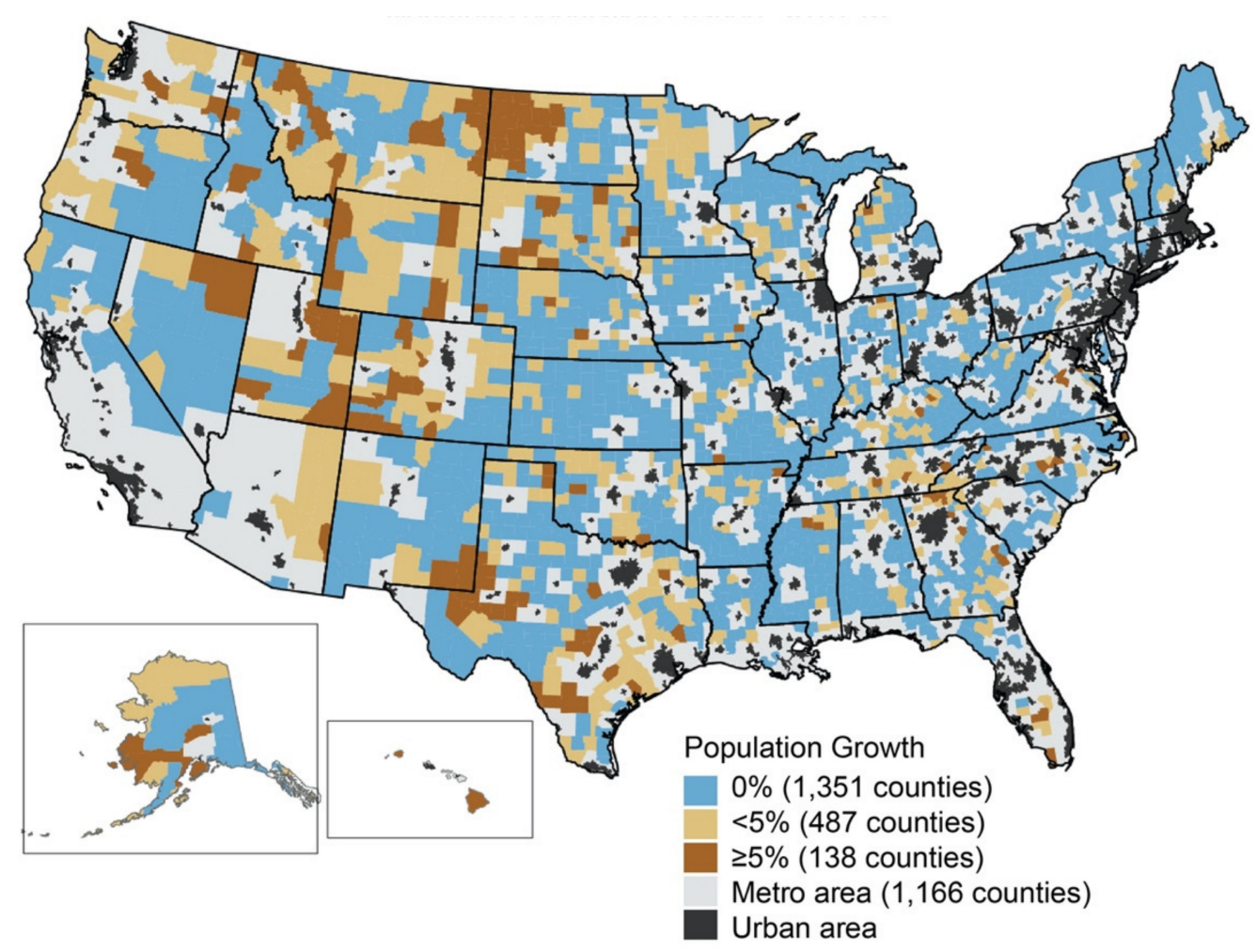

Figure 1. Nonmetropolitan population change, 2010-2016. (Adapted from [12]).

The focus of this study is on the variations in small town rural America and specifically how those changes and transitions are evident in visual landscapes. To understand the current picture in greater detail, a typology is developed to depict the varying stages of contemporary devolution and evolution. The typology is used to describe the landscapes in two rural areas, one in Northwest Iowa and one in Central Maine. As the title indicates, places or areas of rural American abandonment are considered on a continuum from places that once had a settlement of some kind and are now only a memory of "what was," to places having a "mix" of old and recycling land uses, to other places that are experiencing some economic and social renaissance that is evident in the visual landscapes. 
Before presenting the typology devised and methodology used to examine changes in the study areas, a literature review is presented which shows both the lengthy history of scholars interested in rural demographic, economic, and social issues, and how many similar themes are being addressed by scholars from social and policy science perspectives. Following the literature review is a discussion about the typology developed by the authors, a typology that identifies five stages in processes related to both devolution and evolution in rural America. Next, the transects used to collect materials are discussed along with the present salient features in those transects, including photographs depicting the various stages.

\section{Literature Review}

Scholarly contributions to changes in rural America have, and still do, come from rural geographers and sociologists, agricultural economists, and environmental and policy scientists looking at past and present changes in the migrations and demographic mix (youth and elderly) of rural America, population declines, economic shifts (agricultural land uses, global corporations, sustainability), suburban development, the impacts of interstate highways, and emerging tourism and recreation economies. These authors depict a different rural economy and economic picture than existed a century ago or even four or five decades ago with the result being the built structure of rural America in a mix of decline and abandonment as well as recycling and renaissance.

Rural geographers, rural sociologists, and economists have a long tradition of studying rural settlements, population and economic changes, economic functions and trade areas, and housing [3,13-18]. In the geographic community, a major focus of this research was on central place theory, a framework that included not only rural settlements and the topics mentioned above but was behind the emerging study of cities and urban geography. A number of pioneering studies in the 1960s and 1970s looked at regularities in settlement hierarchies, trade areas, threshold populations in historical and contemporary periods in Europe, North America, and elsewhere [19-26]. Dispersed cities also became a focus in places experiencing economic and population declines $[27,28]$. Rural sociologists were active during these years; their contributions were mostly on declines in population and retail establishments [29-37]. These early studies by geographers and rural sociologists were better understood in Zelinksy's opus on long-term rural population changes in the United States [38] and in a contemporary context placed by Hart's scholarly work on the geographies of rural economies, settlements, and landscapes [39].

But some geographers studied low-order rural settlements before central place theory became a major focus of urban geographers [40-43], studies on declines in small towns in the Middle West [44-46], and early sociology works [47,48]. Rural sociologists were active, and their contributions were mostly on declines in population and retail establishments [29,31-36,49].

Another major focus of sustained research specifically looked at abandonment in various economic settings. Numerous examples exist, but this discussion is focused on the diversity of topics associated with abandonment and economic/population decline in different settings, such as cleared farmlands and abandonment [39,46,50], the Buffalo Commons proposal for the Great Plains [51,52], studies on mines and quarries or mining towns from California to Appalachia [53-58], lumbering towns [59,60], declining tourism places [61], and declining villages in Kansas [62].

Along these lines, places outside the U.S. were investigated, for example, mining towns in Wales [63], mobile pastoralism in India [64], industrial lands in Portugal [65], brownfield sites in Europe [65-68], rural abandonment features in Spain [69], mining towns in Australia, Canada, Nigeria, Poland, Slovenia, and South Africa [70-72], fishing villages in Korea and Scotland [73,74], declining tourism in England and Australia [75,76], and regenerated landscapes [77].

Related to these studies were examinations of ghost town features in California, Montana, and Oklahoma [53,78,79], and in Australia [80], China [81,82], and Zimbabwe [83]. 
Another group of studies examined the closing of small towns' social services [84] and institutions, including hospitals, libraries, and churches [85-88]. Emergence of "rural ghettos" [89], the role small towns play in American life [90-92], and revitalized main streets [93,94] were also studied.

Other scholars investigated changes in small town landscapes, including abandonment, within a humanistic and historical cultural geographic context. Their work focused on agricultural economies [95], small towns in Pennsylvania [96], frontier migration and settlement in the Dakotas [97], derelict regions in Appalachia [1], reading small town landscapes [98-100], social injustices in small-town Germany [101], and rural landscape changes in the Czech Republic [102].

Some of these works looked at places "bypassed" by new or improved highways adjacent to a settlement in the U.S. [103,104] or "sidetracked" by railroads no longer serving the community [105-107], and in the U.S.S.R. and Russia [108-111], as well as studies which specifically looked at the demise of gas stations [112,113].

In this mix of qualitative rural research, studies that specifically focused on "how to read" a landscape should also be considered. The early works on this "reading" concept [114,115] spawned other research on reading landscapes in studying abandoned places and landscapes in the United States [103,116,117], on North Dakota's demographic changes [118,119], and the American West [120]. In short, there are many challenges facing the interpretations of rural landscapes, whether examined through a historical or contemporary lens.

Not to be excluded from the scholarly research contributions are popular writers who also have contributed to our knowledge about changes in rural America, especially insightful views about what is happening in small towns, less traveled roads, and urban America [121,122]. Photography has been considered another major component of studying these changes $[118,123]$ as well as those who use "repeat photography" in their research [119].

Finally, it is important to cite some studies on topics related to the current study, including those that have focused on booming or boom and bust economics and populations [124,125]. Abandonment and dereliction themes have been extended into urban areas [1,126-132]. How abandoned mining camps have become tourist sites has also been discussed [57]. In a similar vein, Krzysztofik and Kantor-Pietrage examined in detail the abandoned and derelict in a southcentral region of Poland region where they mapped the blackfields (dumping grounds), brownfields (old mining sites), grayfields (lost service functions), and also greenfields and new residential, service, and industrial development in Poland [133].

Many rural areas in the United States have a well-documented pattern of slow growth or population decline caused by both net outmigration and natural decrease [12,134-137]. The Great Recession may have accelerated the difficulties of depopulating rural communities since recent population growth is concentrated in a smaller number of counties $[10,12,138,139]$. Nearly all population growth between 2008 and 2017 took place in metropolitan counties or those immediately adjacent to them, a pattern evident in the two study areas of Iowa and Maine [10,139]. Job growth and prosperity after the Great Recession generally reflects a similar pattern of concentration. Compared to previous recessions, new business growth following the Great Recession has consolidated in a smaller number of places with larger populations while economically distressed counties have become more concentrated in rural areas. As of 2016, not even a quarter of U.S. counties had replaced the businesses they lost in the Great Recession, and rural areas are more volatile and downwardly mobile compared to suburban and urban areas [10,140]. In the Economic Innovation Group's Distressed Communities Index, the number of "distressed" and "at risk" counties and ZIP Codes increased significantly in rural Iowa, Maine, and other states after the Great Recession [140,141]. Vallianatos [142] invoked the Goldschmidt Hypothesis in his reporting on the shrinking farm population, thus reviving the debate about Walter Goldschmidt's study of the effects on large-scale industrialized agriculture on local communities compared to smaller family farms. Goldschmidt's ideas have been studied since the 1940s [143], and his later research in Iowa found that industrialized hog farming produced poorer social and economic returns to the local communities, though this conclusion was rejected in a recent study in Canada [144]. 
Regardless of the relationship between large-scale agriculture and community health, Swenson [10] found that "Small and medium-sized urban areas-and the rural counties that are linked to them-are left with transportation, public works, housing, and commercial bases that they struggle to maintain." Sometimes these marginalized places are even marginalized in a popular culture context [145]. With the recent slowdown in U.S. population growth, persistent outmigration in rural areas is unlikely to improve [146].

The value of the studies cited above is that they provide a framework to improve our knowledge base about abandonment in rural areas, whether they have an agricultural, fishing, forestry, or mining/extractive base. The current study takes these investigations to a different level, viz., to look at visual evidence of evolution or devolution of rural settlements in a region, specifically the built environments and land uses of those places, not an individual small town or settlement.

\section{Methods}

The authors developed a typology of devolution and evolution which graphically depicts the contemporary small-town landscape scene in many rural regions of the United States. The typology has five stages "from death to renaissance": Stage 1-In Memory, Stage 2-End of Life, Stage 3-Treading Water, Stage 4-Recycling, and Stage 5-Renaissance or Revival. The authors made field observations along transects in rural regions in Iowa and Maine, photographed buildings and other sites along each transect, and interviewed local residents to learn of changes they observed in their communities and the histories of individual buildings they photographed. The authors then grouped the photographed buildings and sites into the five stages and selected the photographs that best represented each stage. These methods were used to evaluate the manifestation of population and economic changes on the visible landscape.

\section{Typology Developed to Describe Rural Landscape Status}

While there is much merit in studying an individual rural settlement, perhaps along a highway or railroad, or a county seat in a farming, mining, forestry, or fishing region, there are also advantages of exploring what visible changes are evident within a larger number of nearby rural settlements and farming communities. The geographies of abandonment are observed today in once-healthy mining communities, logging camps, fishing villages, single-industry towns, and previous sites for church revivals, summer youth camps, military bases, hunting grounds, and seasonal parks. The "visible" health of individual settlements is best considered alongside others when looking at rural population declines, shifts in agricultural ownership and land uses, and changes in economic functions (feed stores, agricultural implement dealerships, banks, groceries, hardware stores) and institutions (churches, schools, hospitals, post offices). Small and very small towns today are better examined alongside what is happening around them, especially in light of the increased ease of mobility of the population working, shopping, worshipping, and participating in community efforts. The demographic changes also occurring in many rural areas, specifically the outmigration of many youth and immobility of many rural elderly, are crucial demographic groups who are changing "where one travels" for a variety of necessity and specialty goods and services. The closure of many services that once were a mainstay of small towns and communities, including schools, post offices, churches, stores, banks, farm implement dealerships, and others, has accompanied rural population decline.

From the authors' experiences of having lived and studied in different parts of rural America, a "typology of devolution and evolution" was developed which depicts much of what is occurring in rural America (Figure 2). Five stages comprise this process "from death to renaissance," which graphically depicts the contemporary small-town landscape scene in many rural regions of the United States. In the following section, the transects are described and then photographs from the two routes are presented. 

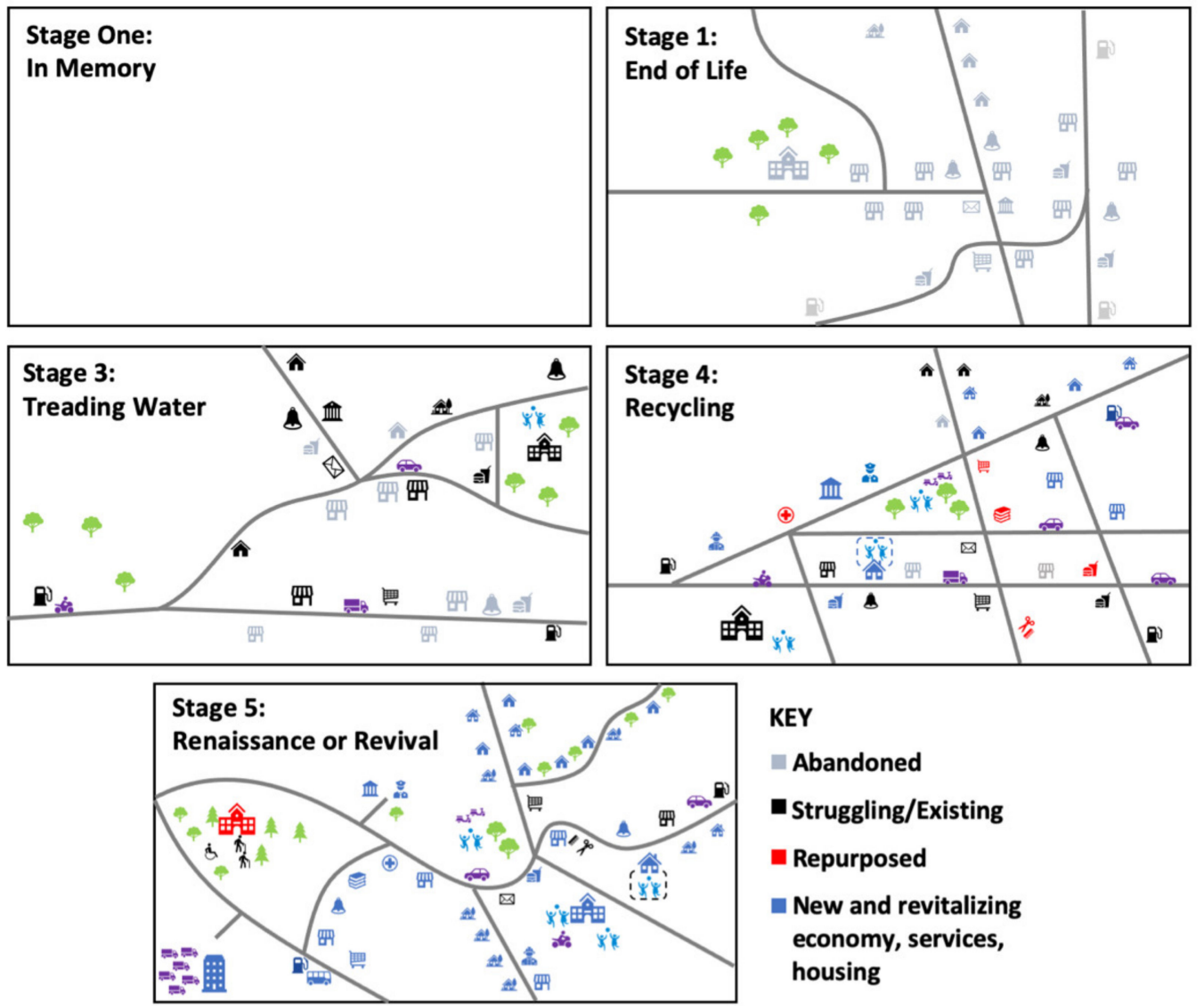

Figure 2. Visual typology of rural devolution and evolution. Stage 1: In Memory. Empty fields, windbreaks, open space, no structures, perhaps a sign of previous place. Stage 2: End of Life. Schools, factories, much dereliction, decay and abandonment, nonfunctional buildings. Stage 3: Treading Water. A mix of abandonment, hanging-on and in-balance, one church open, and others closed, recycled shops, repair shops. Stage 4: Recycling. Reusing existing structures, new exteriors, new post office, mobile home park, gas station/general store. Stage 5: Renaissance or Revival. Access to interstate, new farm and nonfarm economies, new uses, new school and post office.

Stage 1: In Memory. This stage depicts a place that is no longer visible. Those familiar with the place will remember it for what it was. Perhaps there was a grocery store, a church, a school, a bank, a filling station or two. But no visible evidence remains today of "what was." Today the site might be marked by a sign that carried the name of the settlement, but more likely the site today is a plowed field, a pasture or just an empty unused piece of land, or a vacant lot in a town. Memories of the place remain with older generations and perhaps some younger ones who witnessed the final removal of any settlement feature. Perhaps the only memory of a built feature is a windbreak or grove of trees or lane or driveway leading to some feature.

Stage 2: End of Life. The visible landscape of places in this stage will be derelict buildings that are in various stages of disrepair. Standing may be former elementary or high schools, abandoned churches and store fronts, old grain elevators and railroad stations, and perhaps some old farmsteads with empty silos, dairy and hog barns nearby. Also, many empty spaces exist along major and minor streets where homes, stores, and churches once were. The surrounding rural land may exhibit either a thriving or less-than thriving agricultural economy with distinguishing features such as old fence rows, abandoned farm residences, machine sheds, and livestock structures.

Stage 3: Treading Water. This stage is an intermittent stage between "life and death," where the village, small town, and surrounding landscapes contain a mix of shops and institutions that have closed and exhibit end-of-life land uses that exist alongside some shops that are still open, often with 
restricted hours. Communities may have closed elementary schools and a high school, several closed churches and only one open, two closed gas stations and now only one, a closed post office and a closed hospital, but an office for a weekly doctor's visit. Churches are served by "circuit riding clergy" who hold services only one or twice a month in several denominational churches in a region. Where once a new car or farm implement dealer stood, now there may be a small used car dealer and a generic farm repair shop. No library is open, but the community is served by a weekly or biweekly bookmobile service. There might be some new uses of former buildings for community buildings, a hair salon/barber shop, and exercise center. The community square is likely to have open and closed businesses and shops side-by-side. Perhaps a community park or recreation area remains but is likely also to be in some disrepair. Some of these communities may be "bypassed" villages, that is, off major interstate or state highways.

Stage 4: Recycling. Small towns show evidence of "sustainability" because some buildings are put to new uses. These include repair shops that were formerly auto dealers' garages, churches that are now community centers, a laundromat that was a former barber shop, a former gas station selling snacks and pastries, an old school that is now an apartment complex for former farm residents now retiring in towns, or a former bank building that now sells fishing supplies during fishing season. Perhaps a park has some new playground equipment for youth. These towns may also have some features of a "palimpsest landscape," where the land use has changed several times within a couple of decades. One "layer" might include fields and stands of trees that have been converted to hunting preserves and subdivisions. Another layer might be where community hardware stores or post offices have become barber shops, community centers, or one-of-a-kind religious denomination churches. The buildings might have a nice "facelift" with a colorful exterior or some enticing signage describing its new use or owners.

Stage 5: Renaissance or Revival. Small towns in this stage have an active and vibrant economy, in part feeding on the abandonment or demise of other small towns within a 15 to 30 -mile radius. It will have a community school with students coming from rural areas and other small towns nearby, three long-standing churches and one new denomination, a regional hospital, law offices, county library, a new and used car dealership, two groceries and a discount store, a food truck that visits the town several times a week, a hardware store and lumber yard, a cluster of mobile homes for commuters, a former school now housing elderly citizens, a wind and solar farm development, and a used clothing shop. Nearby may be fox hunting clubs, a nationally recognized skiing club, a gated community for a unique cultural or religious group with out-of-state origins, a state park commemorating some significant historical event, a summer retreat for exclusive international elites, or a theme park or casino off a nearby major interstate highway. Perhaps it is a county seat that is benefitting from closures of smaller settlements in the county. These revitalized communities and leisure/retirement services are networked economically to larger places in the urban hierarchy. Palimpsest landscape features are also evident in these places where long-time residents can recall the rural-urban fringe today was previously a dairy farm or used for cropland and today is a retirement center or where today there is the office of a regional hospital, a community center for youth populations, or a thriving day care or exercise center.

The above stages are best considered as "snapshots in time." That concept is illustrated in the final frame of Figure 2. In a hypothetical region, the places now in Stage Two may lapse into Stage One in ten or twenty years, and those in Stage Four may drop into Stage Three in the same time frame. Stage Five towns will benefit from the services now provided in the economic and demographic changes occurring in the other stages.

\section{Results}

\subsection{Testing the Typology-Transects Observed}

The two regions studied by the authors in summer 2019 are in Northwest Iowa and Central Maine; the counties and major roads are shown in Figures 3 and 4. The researchers noted the exact locations of settlements along major and minor roads. 


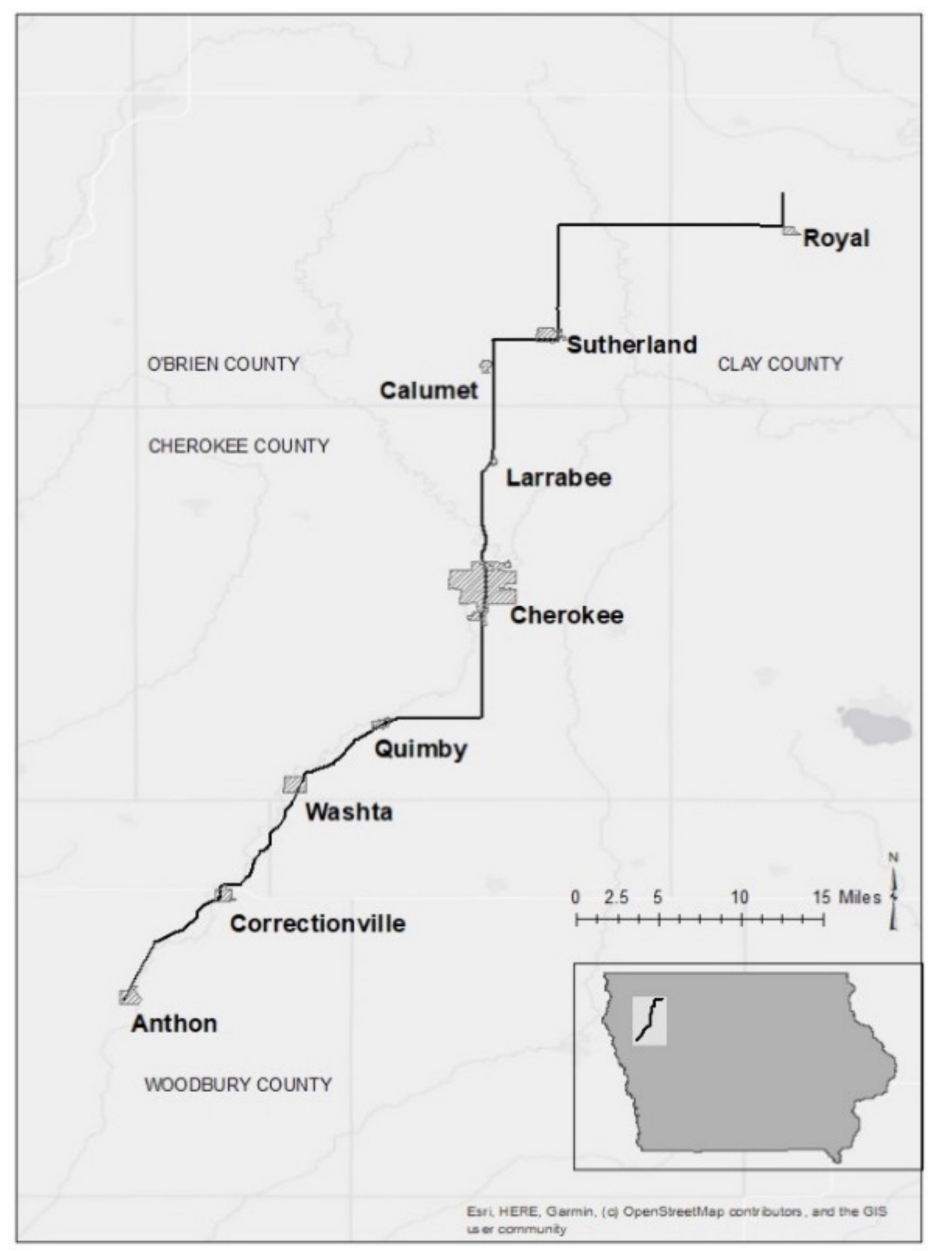

Figure 3. Map of transect across Northwest Iowa.

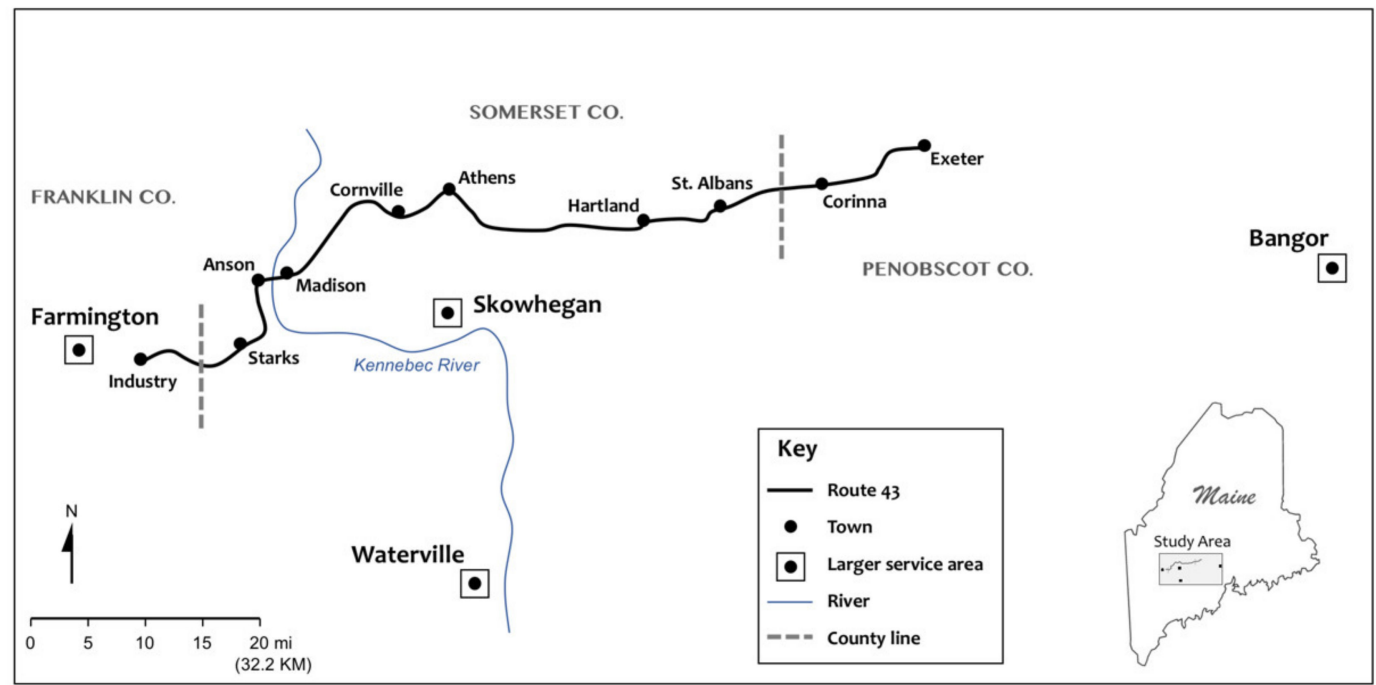

Figure 4. Map of transect across Central Maine.

\subsubsection{The Northwest Iowa Transect}

The Northwest Iowa transect, approximately 70 miles, roughly follows the Little Sioux River through four counties: Clay, O'Brien, Cherokee, and Woodbury County (Figure 3). The route begins on a gravel road that runs north from Royal and ends in the town of Anthon. From Royal, the route follows county highways B40 and M12 to Iowa Highway 10, which passes through Sutherland. From there it 
goes to U.S. Highway 59 through Calumet, Larrabee, and Cherokee, and then to Iowa Highway 31, which goes to Quimby, Correctionville, and Anthon. Cherokee, having a total population of just under 5000 in 2017, is the largest of the eight towns on the transect, and is the county seat of Cherokee County. Royal (415), Sutherland (602), Calumet (160), Larrabee (132), Quimby (293), Correctionville (801), and Anthon (560) had a combined population of 2963 in 2017, and all towns had significant population decline since 2000. The author photographed 77 sites on this route and interviewed residents to learn the history of most of the buildings in or near the towns.

Most of the transect lies in the Northwest Iowa Plains landform region while the southernmost towns of Correctionville and Anthon are in the Loess Hills landform region [147]. Four of the eight towns are immediately adjacent to the Little Sioux River and the other four are in relatively close proximity. The four counties have typical Corn Belt agriculture with high-yielding corn and soybean farms and large hog and cattle production facilities. Meat packing and processing have been important economic activities in the four counties for more than a century. The Sioux City Stockyards became the largest stockyards in the United States in the 1970s before its eventual closing in 2000, the result of a post-WWII shift from rail transportation to interstate trucking and other changes in the industry. The Sioux City Metropolitan Statistical Area still has several meat plants, and both Spencer and Cherokee have had intermittent meat packing, refrigeration, and processing plants for decades. Spencer's facility has changed owners but is still operating as a refrigerated meat warehouse and processing plant that employs about 100 people. Cherokee's plant has experienced several changes in ownership and has closed two times since 2014, leaving about 400 people unemployed after the first closure. While Sioux City lost an iconic regional symbol when its stockyard closed, the recent closure of the meat plant in Cherokee probably had a greater economic ripple effect through the local economy [148-150].

If the vacant meat plant in Cherokee signals a town with significant challenges for communities in rural Iowa, then abandoned buildings in the other seven towns on the transect reveal even greater challenges because of their much smaller populations. Many rural counties in Iowa and other Midwest and Great Plains states continue to lose population, thus making it increasingly difficult to support local businesses, schools, and library services [138,151-153]. Of the four counties in the study area, Woodbury County gained a meager 0.4 percent in population between 2010 and 2018, and the three others lost between 3.2 and 6.2 percent of their populations [139]. Research shows that the Great Recession compounded these problems [152,154,155]. Despite the population losses, this study of buildings in the area shows some surprising signs of sustainability even in places experiencing the loss of some businesses and services.

Most of the buildings and other structures in this transect were in the Recycling (34, 47\%) or End of Life $(29,40 \%)$ stage, which is a sign of distressed places. Of these, most were in the downtowns of the small towns of Calumet, Quimby, Correctionville, and Anthon, thus the small towns are overrepresented in comparison to the largest town of Cherokee, which has many open businesses and fewer abandoned or recycled buildings that were not included in this study. The smallest number of observed locations were in the In Memory $(2,3 \%)$ stage, though more surely exist. Treading Water $(4,5 \%)$ and Renaissance or Revival $(4,5 \%)$ had the same small number of locations.

\subsubsection{The Central Maine Transect}

The entire Maine area is about two hours north of the state's largest city, Portland (population 67,000). Significant service centers within one hour are Farmington (population 7700) to the west, Skowhegan (population 8200), Waterville (population 16,000), and Augusta (population 18,000) all to the south, and Bangor (population 32,000) to the east. Interstate 95 sweeps parallel to the route, 10 to 30 miles to the south.

Central Maine and New England is a region with a long settlement history. Europeans arrived in the study area in the late 1700s and the built environment contains relics from each population that has occupied the land since then [156,157]. The selected 71.7 mile $(115.7 \mathrm{~km})$ transect follows State Route 43 from the Farmington/Industry town line in Franklin County across Somerset County to 
the Exeter/Corinth town line in Penobscot County (Figure 4). Traveling west to east, the researchers observed 231 sites of rural abandonment representing each stage of the typology devised. The transect passes through an economically distressed region of long economic decline that has produced a countryside littered with visual elements of abandonment. They include a wide variety of built features (homes, farms, mills and factories, stores, fairgrounds, schools, churches, government buildings) and transportation features. Observations revealed many changes in this area. The numbers recorded in each of the five typology stages in this traverse were Memory (15, 6.5\%), End of Life (70, 30\%), Treading Water $(68,29.5 \%)$, Recycling $(37,16 \%)$, and Renaissance $(41,18 \%)$.

The west end starts in the steep slopes and rocky soils of the western mountain foothills, while the eastern terminus is in a relatively level, somewhat stone free, deep soiled area. Rivers and streams with large and small cropland intervals and waterpower sites for mills cross the route. Most land is forested. Settlement consists of small mill villages/hamlets, farms, rural year-round and seasonal homes, and associated service/commercial buildings. This area is removed from the "Money Coast," "Ski Resorts," and the "Big North Woods" that shape the state's image and draw tourist dollars. Hard times have been part of the economy and culture for much of its memory. Agriculture, wood harvesting, and mills have all suffered job loss. Service function employment opportunities have moved to larger places as roads and cars improved. The 10 towns along the transect had a combined population of 18,345 in 2010 [158]. A former paper mill town, Madison, was the largest of these towns with 4855 residents. The other nine towns have an average population of 1499 ranging from 640 to 2511 . From 1880 to 1970, little change occurred as the smaller communities declined and Madison grew. Since 1970, the towns have increased by $40 \%$, in part because better automobiles and roads allow people to live greater distances from their employment. Commuting ranges have been extended and employees now travel to the area from Farmington to the west, Waterville/Skowhegan to the south, and Bangor to the east. Retirement homes are also popular in many locations.

\subsection{Findings Regarding the Northwest Iowa Transect}

In Memory: The former unincorporated settlement of Discord (Figure 5) is the best representation of complete abandonment. Discord had a post office from 1870 to 1884 and is now marked only by a sign [159]. The other In Memory location is the vacant lot in downtown Correctionville where there was once a dime store adjacent to a longstanding locally owned grocery. The grocery store burned in 2009 and the dime store building was later razed, leaving the town without a grocery, which led to an enterprising community effort to build a new one down the street. This community effort to build a new grocery was a link in the chain of events that eventually produced the building for the end-of-life selection that follows, and highlights both the importance of the local grocery and the difficulty of sustaining one in small towns [160-163].

End of Life: Structures in this stage made up the second largest share, some reaching the end recently, others long ago. The Mercantile in Correctionville (Figure 6) represents the struggle of locally owned grocery stores in all towns on the transect except Cherokee. The Mercantile is a continuation of the story of the burned grocery next to the dime store. It opened in 2012 after residents donated nearly 100,000 USD, and dozens of people volunteered their labor to construct a new building in the location of a building that collapsed in 2010. This building that collapsed was constructed in 1892 as the Columbia Opera House and remained so for decades. It was then a grocery store in the 1960s and 1970s and most recently was the home of a local couple when it fell down [160-163]. Many small communities across the U.S. have turned to community-led efforts like Correctionville's, public funding, and even city-owned grocery stores to avoid becoming food deserts [164-168]. But Correctionville's new grocery store did not last long, closing after six years. A Dollar General opened in 2016 and contributed to the closure of The Mercantile. Dollar General has about 15,000 stores nationwide and publicizes itself as "America's neighborhood general store," but numerous reports tell the story of Dollar General and other dollar store chains driving local groceries out of business [161,167,169-173]. Correctionville remains without a grocery, but the one that burned in 2009 has been rebuilt and recycled as a coffee 
shop [170]. Anthon's grocery closed in 2011 and reopened under new ownership, only to close again, even without competition from Dollar General, and has been vacant for years since [174,175].

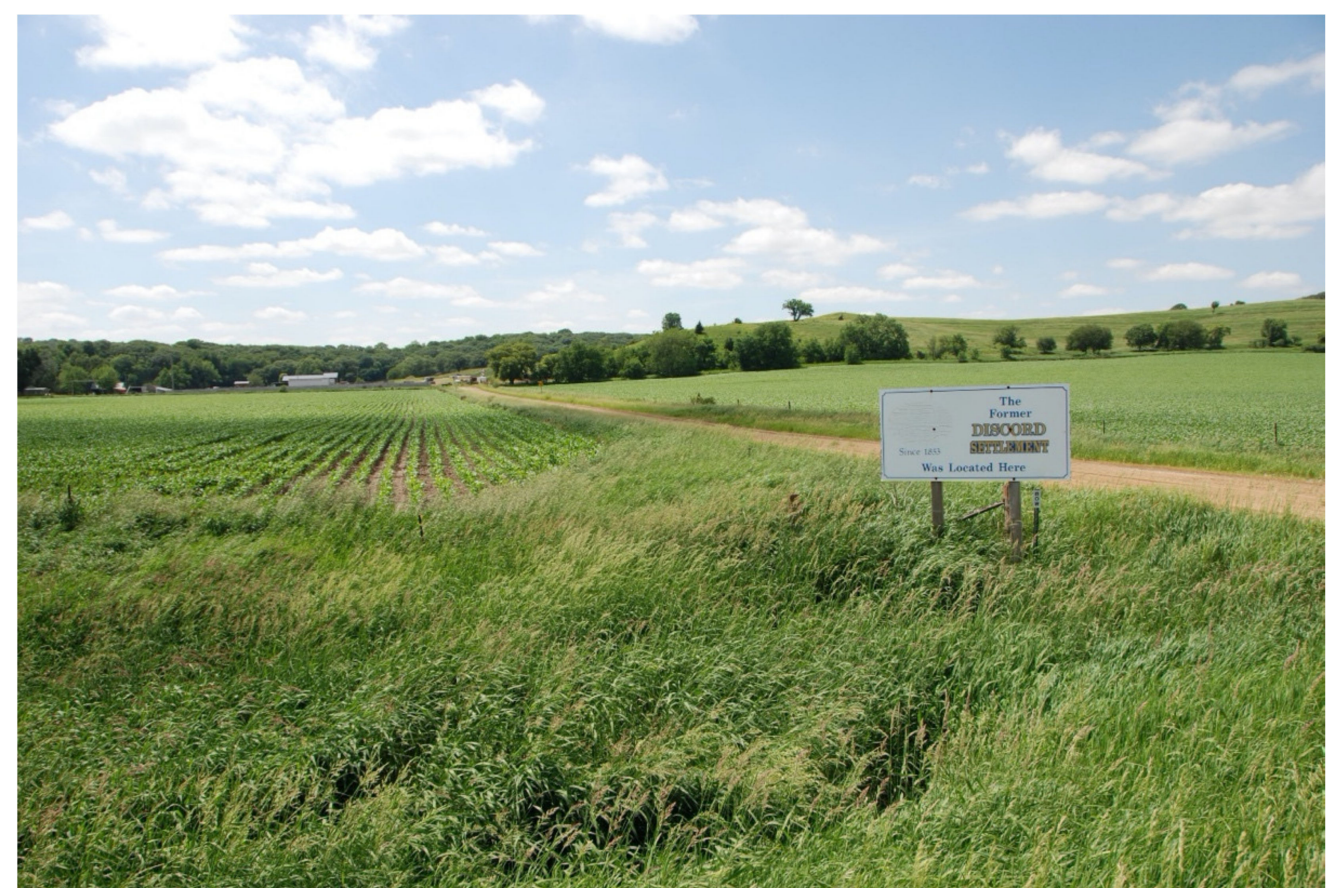

Figure 5. From transect across Northwest Iowa: Stage 1-In Memory. Abandoned settlement of Discord, Iowa.

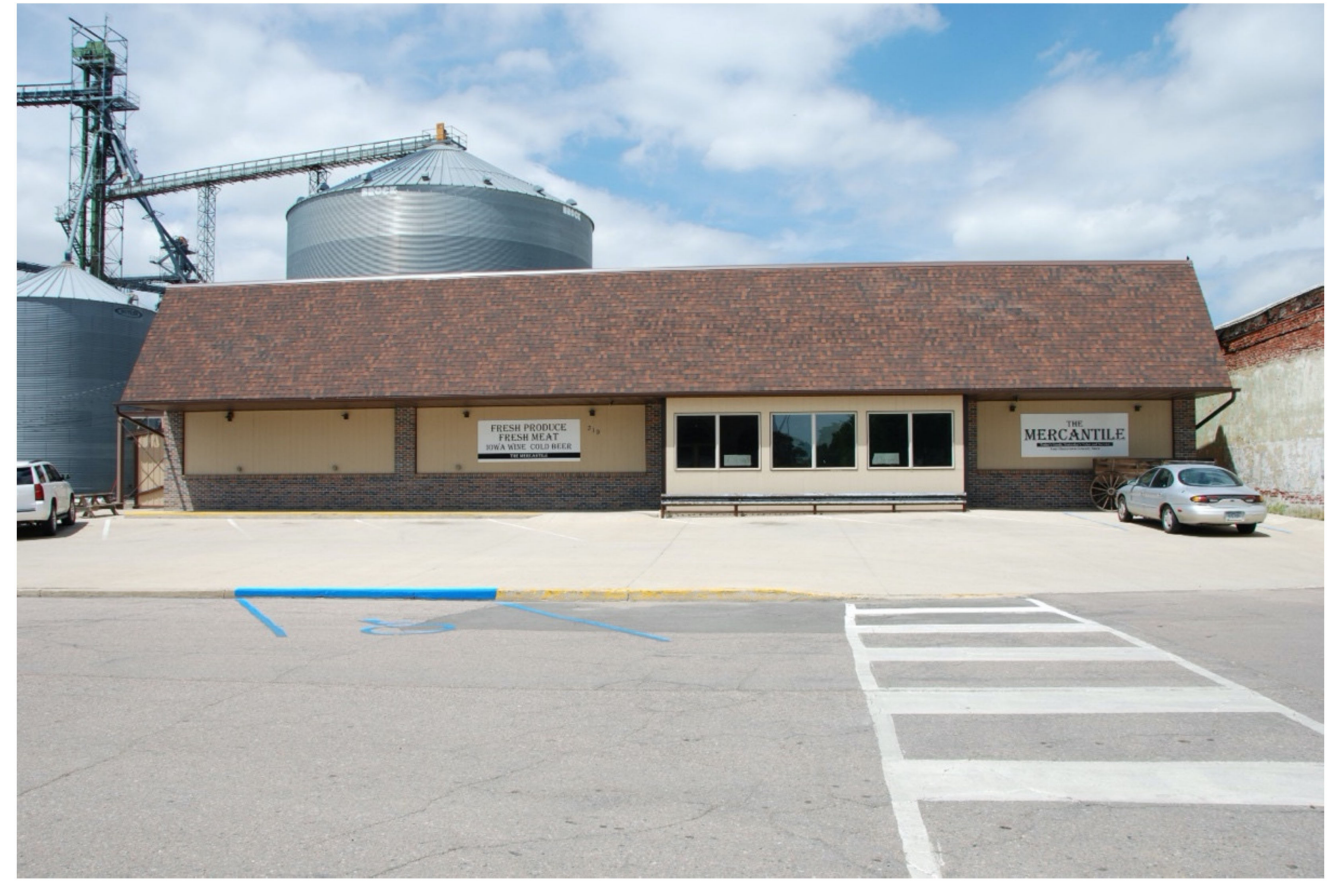

Figure 6. From transect across Northwest Iowa: Stage 2-End of Life. The Mercantile in Correctionville, Iowa.

Treading Water: The meat processing plant in Cherokee (Figure 7) highlights the ups and downs of a major and often controversial employer in Cherokee and other towns and cities where meat packers have located their plants. Wilson Foods opened a beef and pork slaughterhouse in 1965, but the business has been through ownership changes and closures just like many other packing plants in the U.S. Tyson bought the facility in 2001 and processed beef for deli meats but no longer slaughtered the animals there. Tyson closed the aging facility in 2014 and laid off about 450 employees, sending 
a shockwave through the local economy, and then the company refused to give up its lease on the plant to prevent a competing company from purchasing it [176-181]. After years of vacancy, Tyson gave up its lease and a company named the Iowa Food Group bought the plant and reopened it in 2019 to process meat. This was short-lived, however, as the company lost an investor and had to close after only a few months of operation [173-177]. Yet this is not the end of the plant's life, at least for now, because Lopez Foods of Oklahoma purchased the facility and plans to begin its operations in 2020 [149]. Another Treading Water building was the MercyOne Anthon Family Medicine health clinic in Anthon, which has been a doctor's office since it was built. Instead of local ownership by local medical doctors, however, this clinic is now but one in a sprawling network of not-for-profit healthcare facilities located in many states and owned by parent companies in Livonia, Michigan, and Englewood, Colorado [182,183]. Like the meat processing plant in Cherokee, the medical clinic's survival depends on outside ownership and capital. Just as Cherokee is now counting on relying on a company from Oklahoma to keep its plant open, Anthon relies on MercyOne to keep its clinic open.

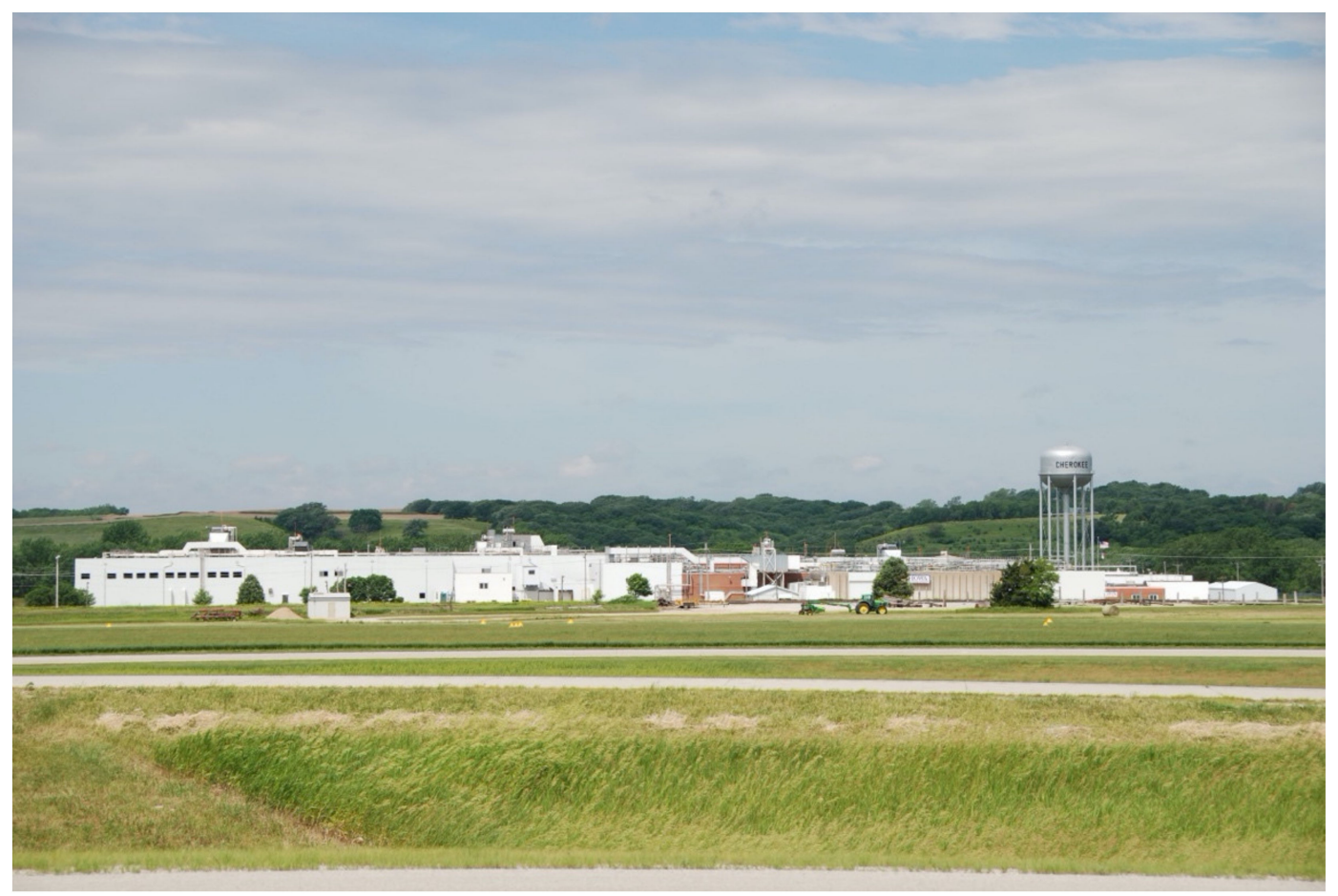

Figure 7. From transect across Northwest Iowa: Stage 3-Treading Water. Meat processing plant in Cherokee.

Recycling: One of the most common buildings in this category was the closed school. Shrinking populations and school consolidations have shuttered original school buildings. In this transect, some are vacant and some are used as community centers, but Sutherland's two former school buildings stood out (Figure 8). Following the closure of one of the school buildings in 1993, community leaders worked hard to turn the building into a multipurpose community center unlike any other on the transect. They began by forming the Sutherland Recreation Corporation (SRC) and built an indoor pool and fitness center. They named the new facility the Willoway Complex, which a local resident coined from "Where there's a will, there's a way." They opened 17 apartments for senior citizens and added a library, salon, commons room, and two apartments for short-term rental [184]. The other school building in Sutherland was also recycled, but in a very different way. During a strike at a meat packing plant in 1978, one striking worker took up stained glass art and turned it into a successful business. After working in several other locations, he purchased Sutherland's closed middle school in 2004 to use as his family's home and glass art studio [185]. These and 32 other observed buildings have been repurposed, and many will likely be repurposed again as businesses close and new businesses open. 


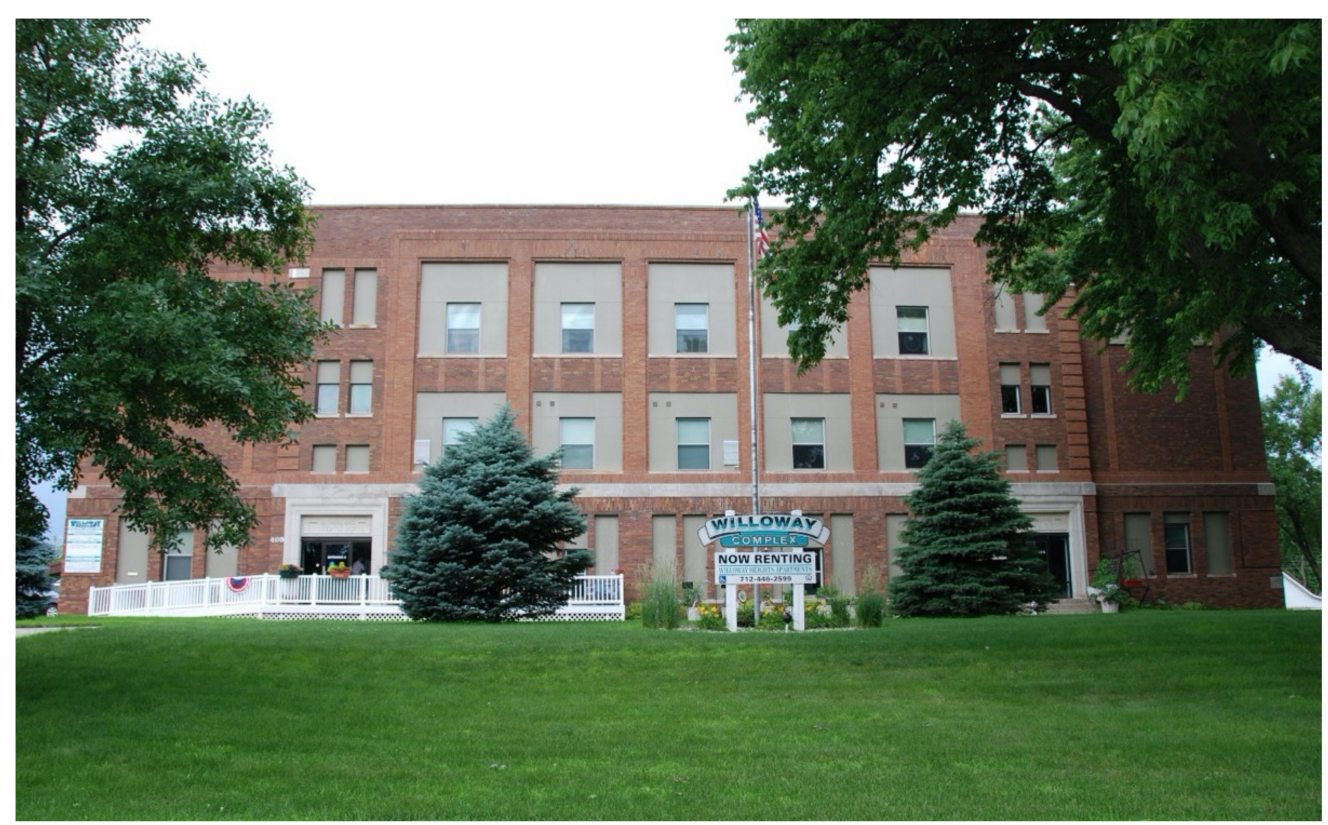

Figure 8. From transect across Northwest Iowa: Stage 4-Recycling. Willoway in Sutherland.

Renaissance or Revival: Even the recycled building successes such as Willoway in Sutherland do not fit the description of a renaissance or revival because long-term sustainability is uncertain as long as population continues to decline. The new Dollar General in Correctionville does not fit either because even though it is new, has financial capital, and does provide communities with necessary goods, it is also responsible for further deteriorating the local businesses. Though not without controversy and opposition in the local communities, the wind turbines north of Royal (Figure 9) and along Iowa Highway 10 represent Renaissance or Revival because they are relatively new, are a source of income for farmers, and provide tax revenue to the local communities [186,187].

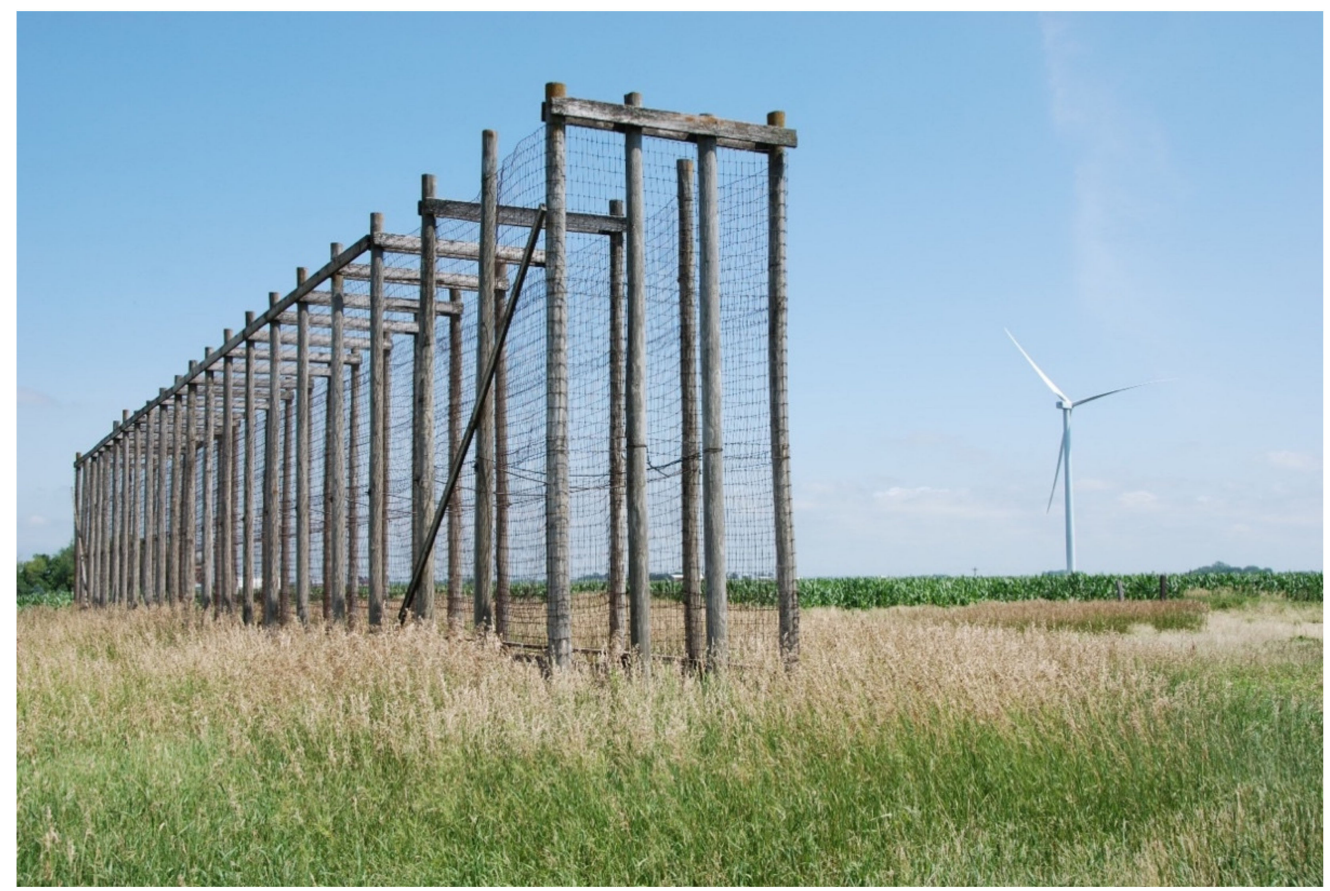

Figure 9. From transect across Northwest Iowa. Stage 5-Renaissance or Revival. Wind turbines and an abandoned corn crib north of Royal. 


\subsection{Findings Regarding the Central Maine Traverse}

In Memory: Taylor/Sinclair/Gilbert auto repair shop in Industry (Allen's Mills Village) operated for decades under several ownerships (Figure 10). The business closed with the retirement of Mr. Gilbert in the 1990s. The building was taken down and the land is now part of a small subdivision. Even though the location is near a popular lake and close to Farmington, it has not sold many lots. The real estate boom and bust cycle make land speculation a gamble that results in some long vacant spaces.

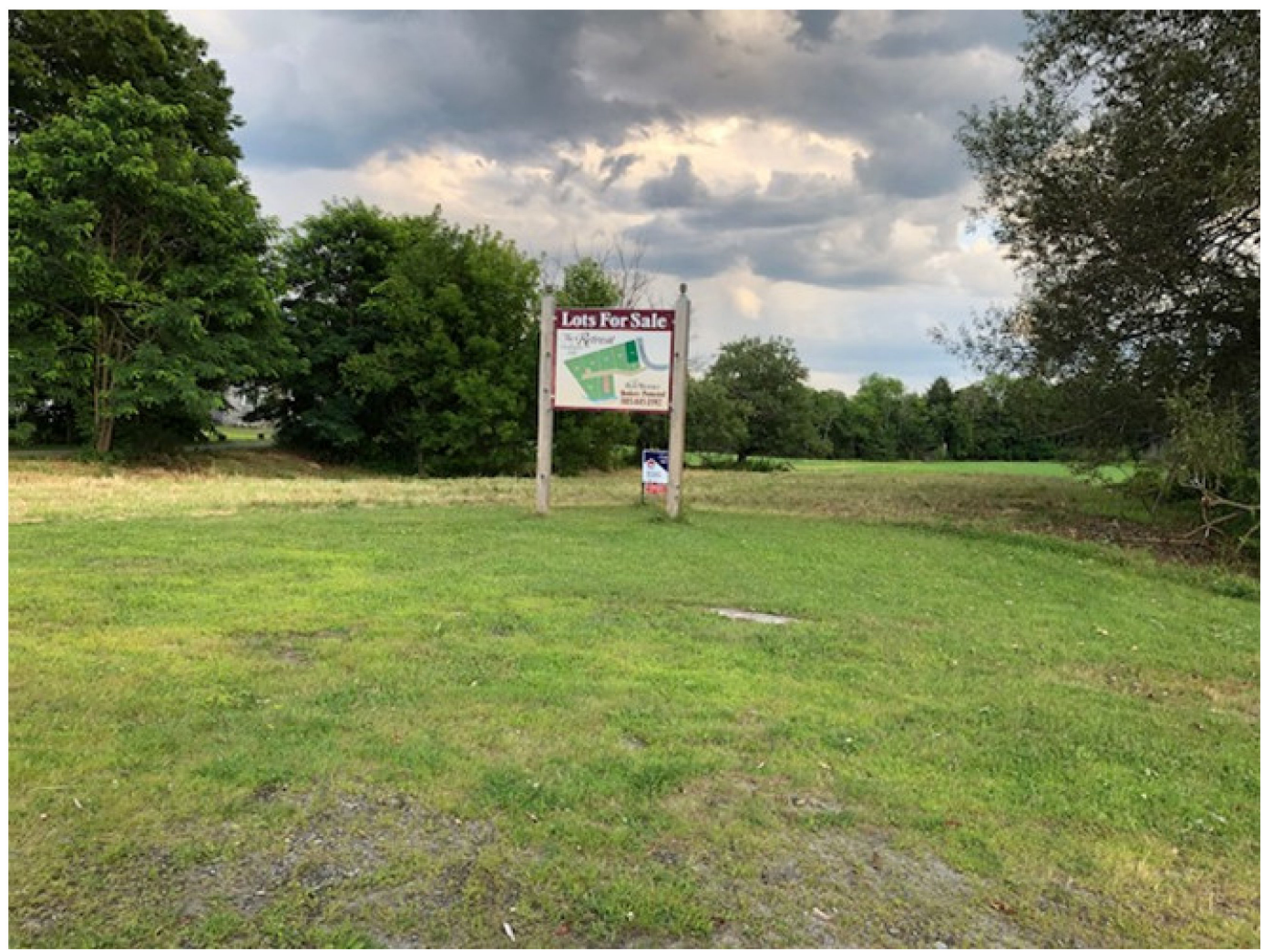

Figure 10. From transect across Central Maine: Stage 1-In Memory. Location of former auto repair shop that stood where the subdivision sign is in Industry, Maine. (Photo courtesy of Betty Austin).

End of Life: Boston's filling station and store (Figure 11) in Athens operated into the 1950s and the building has been in decline since. The place was a favored hangout for both young and old and may have sold more candy than gas.

Treading water: Tasman's Tannery (Figure 12) in Hartland is an example of industries that developed at small waterpower sites and transitioned to modern technology [179]. The business has struggled with changing markets and environmental issues $[188,189]$. The researcher discussed the situation with Elmer Littlefield, past Vice President of the Hartland Historical Society and current member of the town budget committee. Under different owners, the plant has been in bankruptcy three or four times during the past few decades. Fifty years ago, it employed 500-600 people. Today its workforce is about 150. Many of the company's surplus buildings were removed during the past four years. A current planning problem for Hartland's municipal government is the sizing of the wastewater treatment plant. It was built to meet the volume associated with what the tannery produces in addition to other community needs. If the tannery closes, low volume will not allow the processing system to function properly. Town leaders are considering ways to rebuild the plant for a smaller flow if the future warrants. Planning for shrinkage is one of the challenges facing small population clusters that are expected to lose businesses and people. Many of these communities have neglected to make the changes needed to accommodate their shrinking population. They are easy to spot in rural America. 


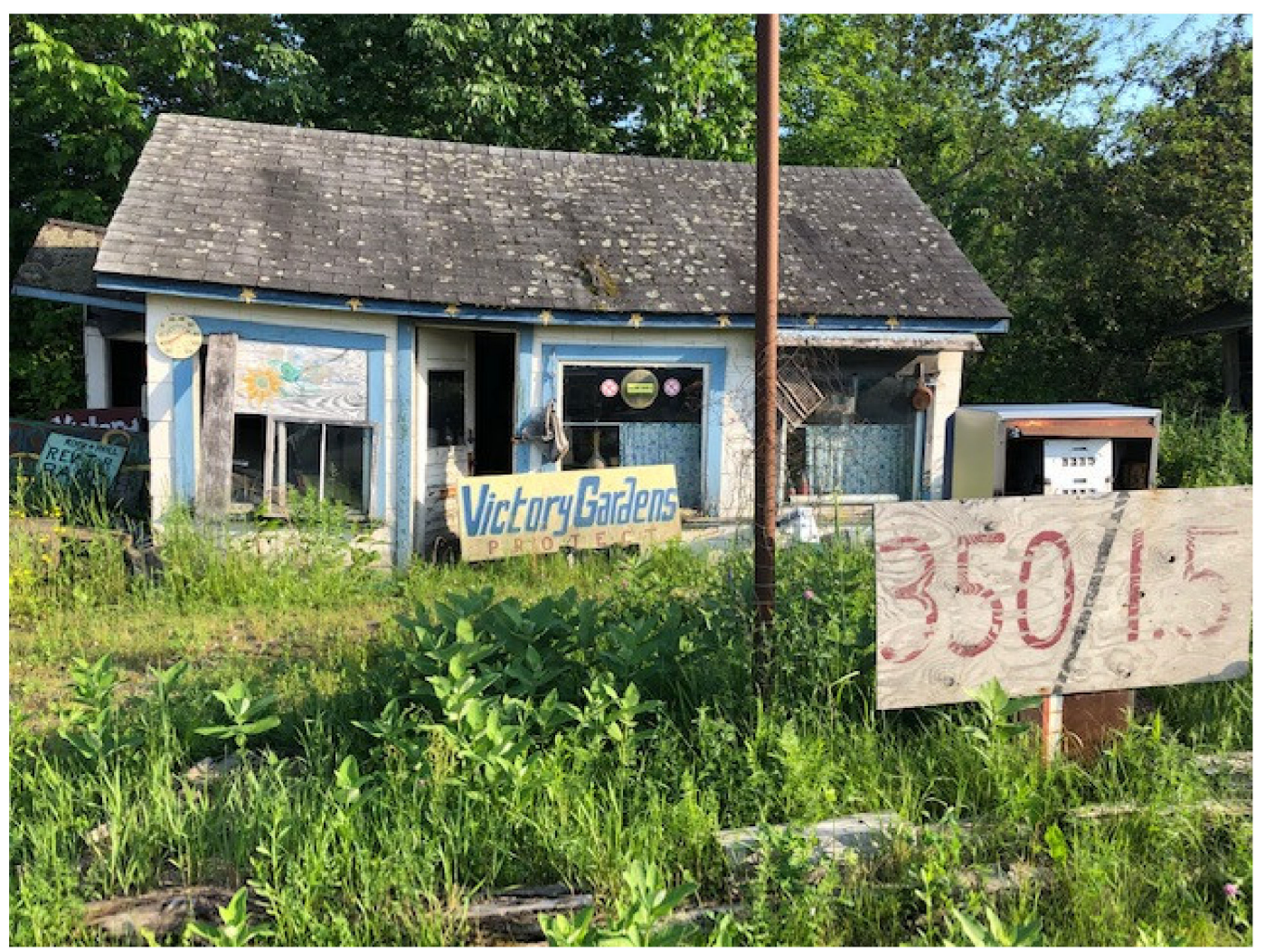

Figure 11. From transect across Central Maine: Stage 2-End of Life. Boston's filling station, Athens, Maine. (Photo courtesy of Betty Austin).

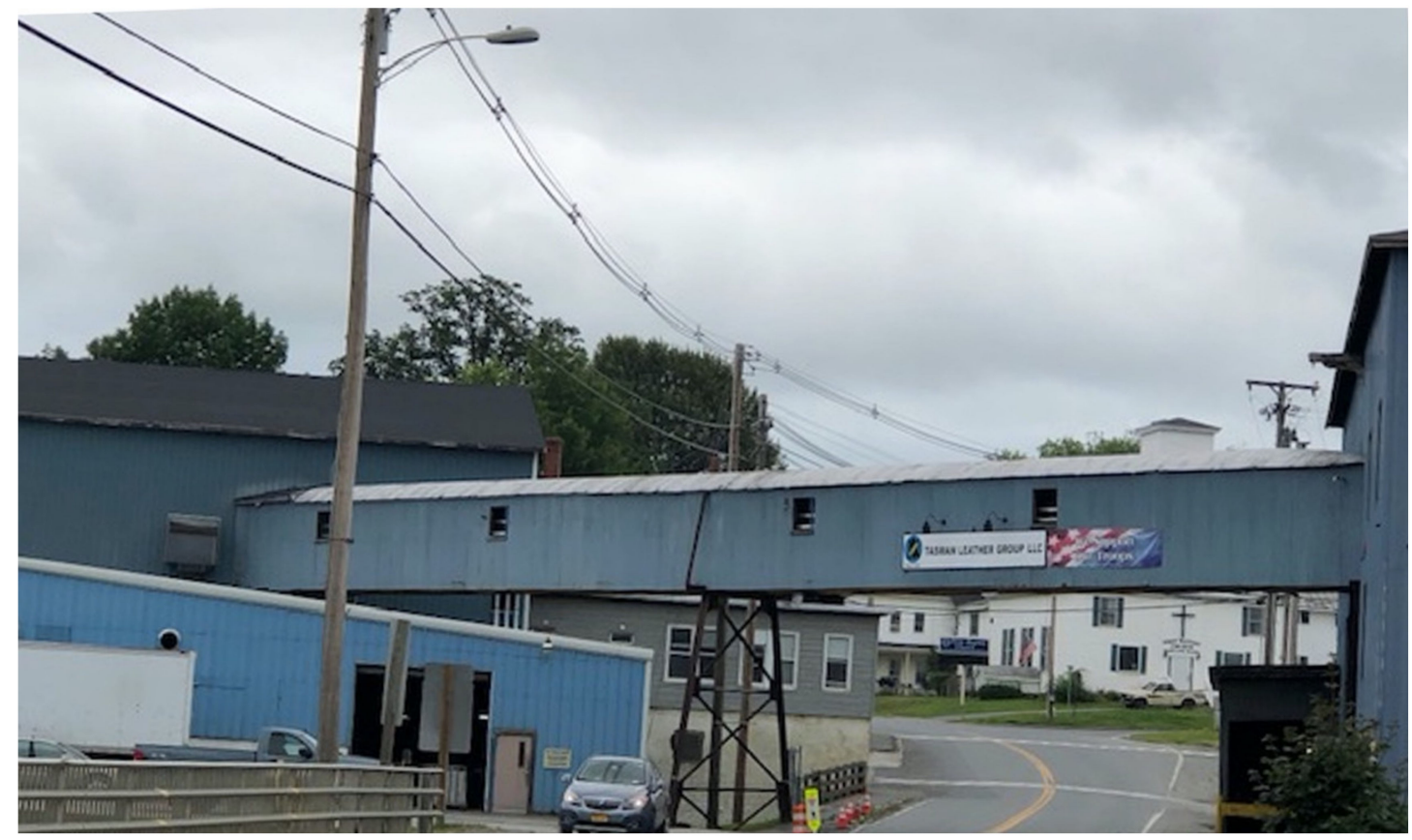

Figure 12. From transect across Central Maine: Stage 3-Treading Water. Route 43 passing through the Tasman tannery complex in Hartland, Maine. (Photo courtesy of Betty Austin).

Recycling: The recycling category features building uses that are common to the region but new to the site. Economy Guns, Economy Archery, Economy Trophy (Figure 13) provides an example of a space that has been transitioned to a different purpose as needs and opportunities have changed over time. The establishment occupies a prime location in Madison's business district. Until 2015, the 
business was simply Economy Trophy and operated out of a small shop. A nearby larger building had a long history as a troubled bar and was forced to close. This was Madison's last public drinking establishment. Mill towns such as Madison have their share of nightlife when employment is high. As jobs go away, so does the after-dark social scene. Soon the trophy business moved into the bar building and added new products and service lines. This is a full-service gun range and appears to be a popular stop for shooters. Local recreational gun users fire away along with tourists, many from outside the United States. Individuals from places with restrictive firearm regulations get special joy. The owner, Robert Hagopian, notes that most Maine towns of any size have a gun shop and he takes pride in his. The Economy range is one of few in the state located in a downtown and draws much of its activity during the cold season.

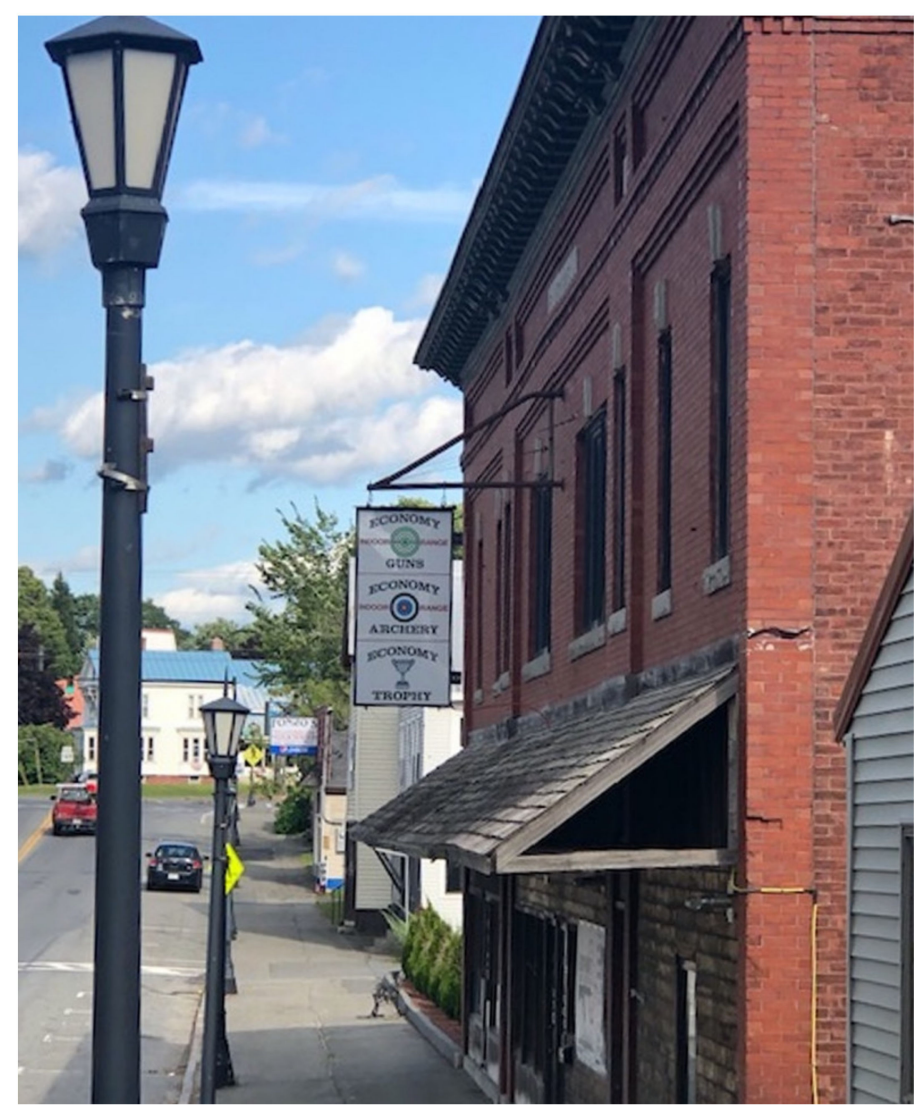

Figure 13. From transect across Central Maine: Stage 4-Recycling. Former bar now gun shop and shooting range in downtown Madison, Maine. (Photo courtesy of Betty Austin).

Renaissance: Businesses and land uses observed in this category represent new and innovative products and services to the study area and have long-term growth potential. Changes in government regulations and product development are significant forces that drive the process. This trend, along with basic success and business expansion, encourages optimism and results in a renaissance at some level. Wicked Lettuce (Figure 14) is a marijuana shop that occupies the tallest building in Madison's business district. Past uses of the property include hardware store and flower/clothing enterprise. The top floors house apartments. The current owners purchased the building two years ago and sell clothing, medical marijuana, and products related to use of the cannabis plant. Recent changes in Maine's regulation of cannabis and its various products have created new opportunities for the business world. What had been a crime a few years back is now legal. Nearby Starks is Maine's epicenter of the decades long struggle to legalize the "Happy Smoke." The battle has left stress scars on the local population as the industry's structure continues to evolve [190]. Stores selling marijuana and associated items have appeared along local roads and in towns. This new set of goods and services has 
generated many different projections about their future. Will consumers buy large amounts and keep profit margins healthy or will demand lag behind supply, driving down return on investment? The family that owns Wicked Lettuce has made significant improvements to the property. A summer 2019 paint job to the old place has transformed it from a weathered eyesore that dominated downtown into a nice-looking structure, improving the appearance of the whole town [190]. A place that looks good is more inclined to generate a renaissance attitude.

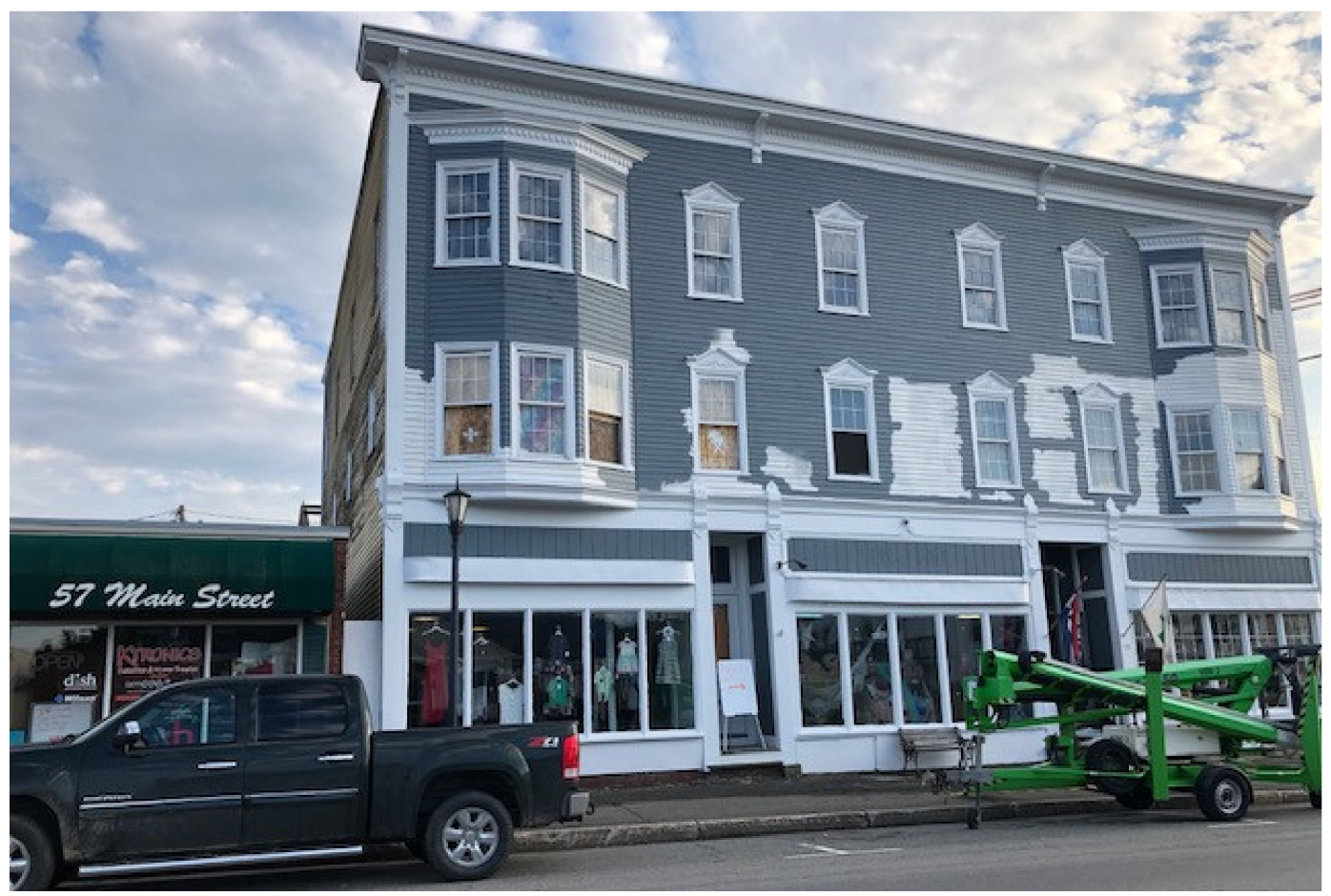

Figure 14. From transect across Central Maine: Stage 5-Renaissance. Marijuana shop in Madison, Maine, getting a facelift (September 2019). (Photo courtesy of Betty Austin).

\section{Discussion}

The observations from the transects across Northwest Iowa and Central Maine make three points very clear. First, villages and towns in rural America exhibit a wide degree of diversity from total or nearly complete abandonment to some degree of renaissance or revival. Where a town fits in the typology developed and tested depends on several related factors. Proximity to a major highway is likely to spur some degree of newness or recycling. The same holds true if the place is near a major metropolitan area where residents can commute to nearby suburban places for employment or for shopping and entertainment. Second, the abandonment features in small towns and villages are far from uniform with some places in an end-of-life stage or close to it. The numbers and densities of abandoned stores, residents, schools, and other features reflect some lengthy outmigration of residents and families, perhaps to a larger nearby place where vital services, including health care, discount stores, and personal services are more readily available. More studies are needed that focus on the demographic groups living in these rural settlements, not only the elderly and long-time residents, but also newcomers and the possible neglect or disengagement of children, teenagers, and young adults [191]. The third noted feature is at the other end of the typology; it is marked by recycled buildings and land uses and a renaissance of goods and services for a small but thriving population. New and colorful building facades attest to an atmosphere where revival, restoration, and renaissance are observed. These upbeat built environments are likely to be the result of a variety of groups actively engaged in bettering the life and atmosphere of the residents. Closer inquiries into the renaissance atmosphere are likely to reveal cooperation of residents, professionals, businesses, churches, and others seeking ways to provide a meaningful and engaging life for long-time and new residents. Many of 
these small settlement nodes are county seats which attract former residents in rural areas and smaller rural settlements nearby.

The typology is a useful model to understand the temporal and spatial dynamics in rural and small-town America. Its key feature is that it examines settlements along a major road rather than a single settlement. It would be useful to test the typology in different rural environments along or distant from major national and state highways. These might be old and new farm economies, seasonal leisure/tourist economies, mining communities, or forest industry regions. Specific locations might be agricultural and mining communities in Appalachia, Mountain West, fishing villages in Maine, coastal economies in the Florida Panhandle, and the Carolinas, and seasonal tourist havens in Michigan's Upper Peninsula and Northern Wisconsin. The methodology also merits testing in rural settlement regions that are only recently experiencing population decline. Analyses of the evolution and devolution patterns may exhibit some differences from what is proposed and was detected in this article, or they may be more alike.

\section{Conclusions}

Reading the contemporary American rural landscape is a complex task, where both abandonment and despair exist, often side-by-side. Observing and visualizing the old, the new, and the renewal are research inquiries that would and should appeal to those in other social and policy sciences, as well as the humanities where place meaning and regional identity/attachment are considered productive lines of further inquiry for those reading the contemporary and the historical. Further in-depth inquiries may reveal that more is at stake than meets the eye. Perhaps what was observed in the current study represents some new hybrid forms of rural settlement that reflect changes in the aging, family, and income structure of a changing America. Perhaps the concept of community itself is being redefined where proximity was the standard feature of residents in a place, but that is being replaced by networks for employment, shopping, friendships, leisure, and worship. Still unknown is the extent to which the internet and social media is changing individual and group identities and relations with others. What is certain is that place, residence, identity, and institutional belonging (nor not belonging) are altering the structures and organization of small towns and villages and those within them or near them. Fluidity, mobility, shrinking time/space technologies, and expanded regional and global networks are the hallmarks of what is shaping much of contemporary rural and urban America. Those features are evident to individuals who have lived in small rural towns and places their entire lives, or are seeking refuge from the hustle and bustle of large cities by retreating to places that may be treading water or experiencing some rebirth. These changes in the economic and social structure of rural communities are acknowledged by Cloke [192], who addresses the need to explore "morality and otherness" and ensure that research findings are available to communities. Liepins [193,194] also notes the dynamics occurring in settlements that are experiencing declines and isolation and whose residents seek a secure place in a globalized world. These dynamic physical, economic, and cognitive worlds include a wider group of scholarly communities that study rural topics. They include professionals who study food production, conservation and preservation, environmental security, tourism and recreation, politics and governance, faith communities, and print and visual media [195]. Woods [2] (page 299) sums up the emergence of new research directions and intersection of scholarly communities well:

"There are many different countrysides. They are distinguished by different landscapes and natural environment, by different histories, settlement patterns and densities of population by relative isolation or proximity to metropolitan areas, by different economic activities, types of farming, industrial development and experiences of economic change and by different patterns of migration and population composition. Even within a single rural territory, people will have very different ideas about what is means to be rural." 
We envision the above quote as an insightful way to explore the temporary and spatial dynamics of a developing and an evolving rural landscape. The need to study these topics is well stated by Hart [39] (page 382), who in a closing statement wrote:

"The structures that people have added to the rural landscape reflect the needs and values of those who are its creators, its inhabitants and its custodians, and we must learn to see it through their eyes to understand and appreciate it fully."

Author Contributions: Conceptualization, S.D.B.; Methodology, S.D.B.; Typology, S.D.B.; Literature Review, S.D.B.; Formal Analysis, J.P.H. and P.F.; Investigation, J.P.H and P.F; Writing-Original Draft, J.P.H. and P.F.; Writing-Editing, S.D.B. All authors have read and agree to the published version of the manuscript.

Funding: This research received no specific funding.

Acknowledgments: Donna Gilbreath assisted with preparation of this manuscript.

Conflicts of Interest: The authors declare no conflict of interest.

\section{References}

1. Jakle, J.A.; Wilson, D. Derelict Landscapes: The Wasting of America's Built Environment; Rowman and Littlefield: Savage, MD, USA, 1992.

2. Woods, M. Rural Geography: Processes, Responses and Experiences in Rural Restructuring; Sage: New Delhi, India, 2005; pp. 91-109.

3. Negi, B.S. Rural Geography; Kedar Nath Ram Nath: Meerut, India; Delhi, India, 1982.

4. Frederic, P. Turning the Bus Around: One Town's Story. Mag. Maine Munic. Assoc. 2012, 74, 17-19.

5. Anderson, P. How South Dakota's Small Grocers are Competing with Dollar General. Sioux Falls Argus Leader, 24 July 2018. Available online: https://www.argusleader.com/story/news/business-journal/2018/07/25 /dollar-general-competition-south-dakota-small-town-grocers/759988002/ (accessed on 19 March 2020).

6. Romell, R. Dollar General's Aggressive Expansion into Small Wisconsin Towns has Hurt Locally Owned Grocery Stores. Milwaukee J. Sentinel 2019, 2. Available online: https://www.jsonline.com/story/money/busin ess/retail/2019/05/23/dollar-general-growth-hits-grocers-wisconsins-small-towns/3620981002/ (accessed on 19 March 2020).

7. Hardy, K. Held 'hostage' by Tyson: An Iowa town's dilemma. The Des Moines Register, 2016. Available online: https://www.desmoinesregister.com/story/money/business/2016/07/08/held-hostage-tyson-iowa-to wns-dilemma/86449400/ (accessed on 19 March 2020).

8. Spross, J. The Unconscionable Abandonment of Rural America. Week, 2016. Available online: https://theweek.co m/articles/628371/unconscionable-abandonment-rural-america (accessed on 19 March 2020).

9. Semuels, A. The Graying of Rural America. 2 June 2016. Available online: https://www.theatlantic.com/busi ness/archive/2016/06/the-graying-of-rural-america/485159/ (accessed on 19 March 2020).

10. Swenson, D. Most of America's Rural Areas Are Doomed to Decline. Available online: http://theconversatio n.com/most-of-americas-rural-areas-are-doomed-to-decline-115343 (accessed on 20 December 2019).

11. Alexander, B. What America Is Losing as Its Small Towns Struggle. 18 October 2017. Available online: https://www.theatlantic.com/business/archive/2017/10/small-town-economies-culture/543138/ (accessed on 19 March 2020).

12. Cromartie, J. Rural Areas Show Overall Population Decline and Shifting Regional Patterns of Population Change; Amber Waves 2017 (Sept 5); USDA Economic Research Service: Washington, DC, USA, 2017.

13. Bunce, M. Rural Settlement in an Urban World; Croom Helm: London, UK, 1982.

14. Chisholm, M. Rural Settlement and Land Use; Hutchinson: London, UK, 1962.

15. Christaller, W. Central Places in Southern Germany; Translation by Baskin, C.W.; Orte, D.Z. in Suddeutschland; Prentice Hall: Englewood Cliffs, NJ, USA, 1961.

16. Clark, C. The stability of village populations. Urban Stud. 1975, 12, 109-110. [CrossRef]

17. Gilg, A.W. An Introduction to Rural Geography; Edward Arnold: London, UK, 1985; pp. 47-66.

18. Lewis, G.J. Rural communities. In Progress in Rural Geography; Pacione, M., Ed.; Barnes and Noble: London, UK, 1983; pp. 149-172.

19. Berry, B.J.L. Geography of Market Centers and Retail Distribution; Prentice-Hall: Englewood Cliffs, NJ, USA, 1967. 
20. Berry, B.J.L.; Garrison, W.L. Recent developments in central place theory. J. Reg. Sci. 1958, 4, 107-120. [CrossRef]

21. Berry, B.J.L.; Garrison, W.L. The functional bases of a central place hierarchy. Econ. Geog. 1958, 34, $145-154$. [CrossRef]

22. Berry, B.J.L.; Barnum, H.G.; Tennant, R.J. Retail location and consumer behavior. Pap. Proc. Reg. Sci. Assoc. 1962, 9, 65-106. [CrossRef]

23. Hodge, G. The Prediction of Trade Center Viability in the Great Plains. Pap. Reg. Sci. Assoc. 1965, 15, 87-115. [CrossRef]

24. King, L.J. The functional role of small towns in Canterbury. In Proceedings of the Third New Zealand Geographical Conference, Palmerston North, New Zealand, August 1961; New Zealand Geographical Society: Palmerston North, New Zealand, 1962.

25. Reeves, D.A.; Gibson, L.J. Town size and functional complexity in a disputed landscape. Yearb. Assoc. Pac. Coast Geogr. 1974, 36, 71-84. [CrossRef]

26. Stafford, H.A. The functional bases of small towns. Econ. Geogr. 1963, 39, 165-175. [CrossRef]

27. Burton, I.A. A Restatement of the Dispersed City Hypothesis. Ann. Assoc. Am. Geogr. 1963, 53, $285-289$. [CrossRef]

28. Stafford, H.A. The dispersed city. Prof. Geogr. 1962, 14, 8-10. [CrossRef]

29. Ballard, P.L.; Fuguitt, G.V. The changing small town settlement in the structure of the United States, 1900-1980. Rural Sociol. 1985, 50, 99-113.

30. Broadway, M.J. Planning for change in small towns or slaughterhouse blues. J. Rural Stud. 2000, 16, 37-46. [CrossRef]

31. Brunner, E. The small village: 1940-1950. Rural Sociol. 1952, 17, 127-131.

32. Fuguitt, G.V. The growth and decline of small towns as a probability process. Am. Sociol. Rev. 1965, 30, 403-411. [CrossRef]

33. Fuguitt, G.V. County seat status as a factor in small town growth and decline. Soc. Forces 1965, 44, $245-251$. [CrossRef]

34. Fuguitt, G.V. The place left behind: Population trends and policy for rural America. Rural Sociol. 1971, 36, 449-470.

35. Fuguitt, G.V.; Brown, D.L.; Bade, C. Rural and Small Town America; Russell Sage: New York, NY, USA, 1989.

36. Fuguitt, G.V.; Thomas, D.W. Small town growth in the United States: An analysis by class size and by place. Demography 1966, 3, 513-527. [CrossRef]

37. Johansen, H.E.; Fuguitt, G.V. Population Growth and Retail Decline: Conflict effects of urban accessibility in American villages. Rural Sociol. 1979, 44, 24-38.

38. Zelinsky, W. Changes in the geographic patterns of rural population in the United States. Geogr. Rev. 1962, 52, 492-524. [CrossRef]

39. Hart, J.F. The Rural Landscape; Johns Hopkins University Press: Baltimore, MD, USA, 1998.

40. Bailey, W.C. A typology of Arizona communities. Econ. Geogr. 1950, 26, 94-104. [CrossRef]

41. Brush, J.E. The hierarchy of central places in Southwestern Wisconsin. Geogr. Rev. 1953, 43, $380-402$. [CrossRef]

42. Davis, C.M. The cities and towns of the high plains of Michigan. Geogr. Rev. 1938, 28, 664-673. [CrossRef]

43. Trewartha, G. The unincorporated hamlet: One element of the American settlement system. Ann. Assoc. Am. Geogr. 1943, 33, 32-81. [CrossRef]

44. Daniels, T.L.; Lapping, M.B. Small town triage: A rural settlement policy for the American Midwest. J. Rural Stud. 1987, 31, 273-280. [CrossRef]

45. Hart, J.F.; Salisbury, N.E. Population change in middle western villages: A statistical approach. Ann. Assoc. Am. Geogr. 1965, 55, 140-159. [CrossRef]

46. Hart, J.F.; Salisbury, N.E.; Smith, E.G., Jr. The dying village and some notions about urban growth. Econ. Geogr. 1968, 44, 343-349. [CrossRef]

47. Chittick, D. Growth and Decline of South Dakota Trade Centers 1901-1951; South Dakota State University, Agricultural Experiment Station: Brookings, SD, USA, 1955.

48. Smith, T.L. The role of the village in American rural society. Rural Sociol. 1942, 7, 10-21.

49. Dahms, F.A. 'Dying Village,' 'Counterurbanization' and the Urban Field-A Canadian perspective. J. Rural Stud. 1985, 11, 21-33. [CrossRef] 
50. Benjamin, K.; Bouchard, A.; Domon, G. Abandoned farmlands as components of rural landscapes: An analysis of perceptions and representations. Landsc. Urban Plan. 2007, 83, 228-244. [CrossRef]

51. Popper, D.E.; Popper, F.J. The Great Plains: From dust to dust. Planning 1987, 53, 12-18.

52. Popper, D.E.; Popper, F.J. The Great Plains and the Buffalo Commons. In Worldminds: Geographic Perspectives on 100 Problems; Janelle, D., Warf, B., Hansen, K., Eds.; Springer: Dordrecht, The Netherlands, 2007; pp. 345-349.

53. Dilsaver, L.M. After the Gold Rush. Geogr. Rev. 1985, 75, 1-18. [CrossRef]

54. Edwards, J.A.; Li Coit, J.C. Mines and Quarries: Industrial Heritage Tourism. Ann. Tour. Res. 1996, 23, 341-363. [CrossRef]

55. Gradwohl, D.M.; Osborn, N.M. Exploring Buried Buxton: Archaeology of an Abandoned Coal Mining Town with a Large Black Population; University of Iowa Press: Iowa City, IA, USA, 1990.

56. Marsh, B. Continuity and Decline in the Anthracite Towns of Pennsylvania. Ann. Assoc. Am. Geogr. 1987, 77, 337-352. [CrossRef]

57. Prideaux, E.; Timothy, D. From mining towns to tourist haunts: The ghost town life cycle. In Mining Heritage and Tourism; Cronin, M.V., Joliffie, L., Eds.; Taylor and Francis: New York, NY, USA, 2011; pp. 227-238.

58. Sherman, J.E.; Sherman, B.H. Ghost Towns and Mining Camps of New Mexico; University of Oklahoma Press: Norman, NM, USA, 1975.

59. Godfrey, L.G. Hemingway and cultural geography: The landscape of logging "at the end of something. " Hemingway Rev. 2006, 26, 47-62. [CrossRef]

60. Stokes, G.A. Lumbering and western Louisiana cultural landscapes. Ann. Assoc. Am. Geogr. 1957, 47, 250-266. [CrossRef]

61. Davis, J.S.; Morais, D.B. Factions and enclaves: Small towns and socially unstable tourism development. J. Travel Res. 2004, 43, 3-10. [CrossRef]

62. White, S.S. Farmers and rural Kansas communities: Planning for the future. J. Rural Community Dev. 2014, 9, 227-242.

63. Thomas, T.M. Wales: Land of mines and quarries. Geogr. Rev. 1956, 46, 59-81. [CrossRef]

64. Varma, S. Villages abandoned: The case of mobile pastoralism in post-Harappan Gujarat. Stud. Hist. 1991, 7, 279-300. [CrossRef]

65. Loures, L.; Panagopoulos, T. Reclamation of derelict industrial lands in Portugal: Greening is not enough. Int. J. Sustain. Dev. Plan. 2010, 5, 343-350. [CrossRef]

66. Franz, M.; Cules, O.; Prey, G. Place-making and "Green" reuses of brownfields in the Ruhr. Tijdschrift Voor Economische En Sociale Geografie 2008, 99, 316-328. [CrossRef]

67. Hudson, R. Rethinking change in old industrial regions: Reflecting on the experience of North East England. Environ. Plan. A 2005, 37, 581-594. [CrossRef]

68. Popescu, G.; Patraşcoiu, R. Brownfield sites-between abandonment and redevelopment case study: Craiova city. J. Stud. Res. Human Geogr. 2012, 6, 91-97. [CrossRef]

69. Garcia, A.I.; Ayuga, F. Reuse of abandoned buildings of the rural landscape: The situation in Spain. Am. Soc. Agric. Biol. Eng. 2007, 50, 1383-1394.

70. Binns, T.; Nel, E. The Village in a Game Park: Local Response to the Demise of Coal Mining in KwaZulu-Natal, South Africa. Econ. Geogr. 2003, 79, 41-66. [CrossRef]

71. Marais, L.; McKenzie, F.H.; Deacon, L.; Nel, E. The Changing Nature of Mining Towns: Reflections from Australia, Canada and South Africa. Land Use Policy 2018, 76, 779-788. [CrossRef]

72. Riley, R.; Thocz, M. Local responses to changed circumstances: Coalmining in the market economy in Upper Silesia, Poland. GeoJournal 1999, 48, 279-290. [CrossRef]

73. Cheong, S.M. Korean Fishing communities in transition: Limitations of community-based resource management. Environ. Plan. A 2005, 37, 1277-1290. [CrossRef]

74. Nadal-Klein, J. Granny baited the lines: Perpetual crises and the changing role of women in Scottish fishing communities. Women's Stud. Int. Forum 2000, 23, 363-372. [CrossRef]

75. Smith, M.K. Seeing a new side to seasides: Culturally regenerating the English seaside town. Int. J. Tour. Res. 2004, 6, 17-28. [CrossRef]

76. Tonts, M. The future of Australia's small town. Reg. Policy Pract. 2000, 9, 11-16.

77. Kitchen, T.; Marsden, T.; Milbourne, P. Community forests and regeneration of post-industrial landscapes. Geoforum 2006, 37, 831-843. [CrossRef] 
78. De Lyser, D. Authenticity on the ground: Engaging the past in a California ghost town. Ann. Assoc. Am. Geogr. 1999, 89, 602-632. [CrossRef]

79. Knapp, P.A. Long-term soil and vegetation recovering in five semiarid Montana ghost towns. Prof. Geogr. 1991, 43, 486-499. [CrossRef]

80. Ballantyne, L. Unsettled country: Reading the Australian ghost towns. J. Aust. Stud. 2001, 26, 33-38. [CrossRef]

81. Shepard, W. Ghost Cities of China. The Story of Cities Without People in the World's Most Populated Country; Zed Books: London, UK, 2015.

82. Wordsworth, M.D.; Wallace, J.L. Seeing ghosts: Parsing China's "ghost city" controversy. Urban Geogr. 2017, 38, 1270-1281.

83. Kamete, A.Y. Of prosperity, ghost towns and havens: Mining towns in Zimbabwe. J. Contemp. Afr. Stud. 2012, 30, 589-609. [CrossRef]

84. Caudill, M.A. School social work services in rural Appalachian systems: Identifying and closing the gaps. Child. Sch. 1993, 15, 179-185. [CrossRef]

85. Heuretz, L.; Gordon, A.C.; Gordon, M.T.; Moore, E.J. The impact of public access computing on rural and small-town libraries. Rural Libr. 2003, 23, 51-80.

86. James, A. Closing rural hospitals in Saskatchewan: On the road to wellness? Soc. Sci. Med. 1999, 49, 1021-1034. [CrossRef]

87. Knight, R. Last one out turn off the lights: The influence of geographic, demographic and economic factors on the provision of library service in rural and remote communities. Rural Sociol. 2002, 12, 262-272. [CrossRef]

88. Hart, J.F. The highest form of the geographer's art. Ann. Assoc. Am. Geogr. 1982, 72, 1-25. [CrossRef]

89. Jacobson, G.; Albertson, B.S. Social and economic change in rural Iowa: The development of rural ghettos. Hum. Serv. Rural Environ. 1987, 10, 58-65.

90. Armstrong, J. Everyday afterlife: Walter Benjamin and the politics of abandonment in Saskatchewan. Cult. Stud. 2011, 25, 273-293. [CrossRef]

91. Marshall, D.G. Hamlets and villages in the United States: Their place in the American way of life. Am. Sociol. Rev. 1946, 11, 159-165. [CrossRef]

92. Norris-Baker, C.; Scheidt, R.J. A Contextual approach to serving older residents of economically- threatened small towns. J. Aging Stud. 1991, 5, 333-346. [CrossRef]

93. Le Blanc, F. The Main Street Canada approach to small historic towns. Proc. Inst. Civ. Eng. 2011, 164, 185-193.

94. Paradis, T.W. Conceptualizing small towns as unknown place: The process of downtown redevelopment in Galena, Illinois. Urban Geogr. 2000, 21, 61-82. [CrossRef]

95. Mather, E.C. One hundred houses west. Can. Geogr. 1968, 7, 1-12. [CrossRef]

96. Lewis, P.F. Small town in Pennsylvania. Ann. Assoc. Am. Geogr. 1972, 62, 323-356. [CrossRef]

97. Hudson, J.C. Two Dakota homestead frontiers. Ann. Assoc. Am. Geogr. 1973, 63, 442-462. [CrossRef]

98. Jackson, J.B. The Necessity for Ruins; University of Massachusetts Press: Amherst, MA, USA, 1980.

99. Jackson, J.B. Landscape in Sight; Yale University Press: New York, NY, USA, 1997.

100. Jakle, J.A. America's Small Town/Big City Debate. J. Cult. Geogr. 1999, 8, 1-27. [CrossRef]

101. Bûrk, T. Voices from the margin: The stigmatization process as an effect of socio-spatial peripheralization in small-town Germany. In Peripheralization: The Making of Spatial Dependencies and Social Injustice; Fisher-Tahir, A., Naumann, M., Eds.; Springer: Weisbaden, Germany, 2013; pp. 161-186.

102. Mares, P.; Rasin, R.; Pipan, P. Abandoned landscapes in former German settlements in the Czech Republic and in Slovenia. In Cultural Severance and the Environment; Rotherham, I.D., Ed.; Springer: Dordrecht, The Netherlands, 2013; pp. 289-309.

103. Brouws, J. Highway Approaches Endless Dream; Stewart, Tabori and Chang: New York, NY, USA, 1967.

104. Rogers, C.L.; Marshment, R. Measuring highway bypass impacts on small town business districts. Rev. Urban Reg. Stud. 2000, 12, 250-265. [CrossRef]

105. Hudson, J.C. Towns of the western railroads. Great Plains Q. 1982, 2, 41-54.

106. McIntosh, C.B. Side-tracked villages in east central Illinois. Ann. Assoc. Am. Geogr. 1959, 49, 197-198.

107. Schwieterman, J.P. When the Railroad Leaves Town: American Communities in the Age of Rail Line Abandonment; Truman State University Press: Kirksville, MO, USA, 2001.

108. Rowland, R.H. Recent declining and small towns of the USSR. Sov. Geogr. 1980, 21, 195-218. [CrossRef]

109. Rowland, R.H. Declining towns in the former USSR. Post-Sov. Geogr. 1994, 35, 352-365. [CrossRef] 
110. Rowland, R.H. Declining towns in Russia. Post-Sov. Geogr. 1995, 36, 436-445. [CrossRef]

111. Smith, C.J.; Smith, C.A. Hedography: A plea for back roads. Leis. Sci. 1978, 1, 411-426. [CrossRef]

112. Brouws, J. Twenty-six Abandoned Gasoline Stations; Gas-N-Go Publications: Santa Barbara, CA, USA, 1962.

113. Jakle, J.A.; Sculle, A. The Gas Station; Johns Hopkins University Press: Baltimore, MD, USA, 2002.

114. Lewis, P.F. Axioms for reading the landscape: Some guides to the American scene. In The Interpretation of Ordinary Landscape; Meinig, D.W., Jackson, J.B., Eds.; Oxford University Press: New York, NY, USA, 1979; pp. 11-32.

115. Meinig, D.W.; Jackson, J.B. (Eds.) The Interpretation of Ordinary Landscapes: Geographical Essays; Oxford University Press: New York, NY, USA, 1979.

116. Schroeder, F.E.H. Types of American small towns and how to read them. South. Q. 1989, 19, 104-135.

117. Brouws, J. Approaching Nowhere; W. W. Norton: New York, NY, USA, 1993; pp. 146-157.

118. Jacobs, M.; Rundquist, B.; Bauer, K. Reading North Dakota's contemporary landscapes: Stories of devolution, dereliction, dynamism and curation. In The Handbook of the Changing World Language Map; Brunn, S.D., Kehrein, R., Eds.; Springer: Dordrecht, The Netherlands, 2019; pp. 3015-3046.

119. Wetherholt, W.A.; Vandeburg, G.S. Reading the landscape in Antler, North Dakota: Repeat photography in an atrophying northern plains town. In The Handbook of the Changing World Language Map; Brunn, S.D., Kehrein, R., Eds.; Springer: Dordrecht, The Netherlands, 2019; pp. 3171-3193.

120. Wyckoff, W. How to Read the American West; University of Washington Press: Seattle, WA, USA, 2014.

121. Bryson, B. The Lost Continent. Travels in Small Town America; Harper-Collins: New York, NY, USA, 1989.

122. Humphreys, J.R. The Lost Towns and Roads of America; Doubleday: New York, NY, USA, 1961.

123. Fox, W.L. The Impossibility of Ruins. In Approaching Nowhere; Brouws, J., Ed.; W. W. Norton: New York, NY, USA, 1993; pp. 140-145.

124. Brown, K. Ecosystem recovery. Ghost towns tell tales of ecological boom and bust. Science 2000, $290,35-37$. [CrossRef]

125. Hostetter, E. Boomtown Landscapes. Mater. Cult. 2011, 43, 59-79.

126. Bailey, S. Transforming urban landscapes: Soccer fields as sites of urban sociability in the agglomeration of Dakar. Afr. Identities 2007, 5, 217-230.

127. Bowman, A.O.M.; Pagano, M.A. Terra Incógnita. Vacant Land and Urban Strategies; Georgetown University Press: Washington, DC, USA, 2004.

128. Clay, G. Real Places; University of Chicago Press: Chicago, IL, USA, 1994.

129. Corbin, C.I. Vacancy and the landscape: Cultural context and urban response. Landsc. J. 2003, 22, 12-24. [CrossRef]

130. Greenberg, M.R.; Popper, F.; West, D. The TOADS [Temporarily Obsolete Abandoned Derelict Sites]: A New American Epidemic. Urban Aff. Rev. 1990, 25, 435-454.

131. Groth, R.; Groth, P.E.; Bressi, T. (Eds.) Understanding Ordinary Landscapes; Yale University Press: New Haven, CT, USA, 1997.

132. Mah, A. Industrial Ruination, Community and Place: Landscapes and Legacies of Urban Decline; University of Toronto Press: Toronto, ON, Canada, 2012.

133. Krzysztofik, R.; Kantor-Pietraga, I. A dynamic approach to the typology of functional derelict areas (Sosnowiec, Poland). Morav. Geogr. Rep. 2013, 21, 20-35. [CrossRef]

134. Frey, W.H. A Population Slowdown for Small Town America; Brookings Institute: Washington, DC, USA, 2014.

135. McChesney, R.; Overberg, G. Is Negative Population Growth Upon Us? Deaths Exceed Births in One-Third of U.S. Counties. NewsGeography, 5 May 2012. Available online: https://www.newgeography.com/content/0 02812-is-negative-population-growth-upon-us-deaths-exceed-births-one-third-us-counties (accessed on 19 March 2020).

136. Peters, D.J. Iowa Population Over 100 Years; Extension Community and Economic Development Publications: Ames, IA, USA, 2011; p. 27. Available online: https:/lib.dr.iastate.edu/cgi/viewcontent.cgi?article=1008\&co ntext=extension_communities_pubs (accessed on 19 March 2020).

137. Sullivan, R.; Aging and Declining Populations in Northern New England. Is There a Role for Immigration? Federal Reserve Bank of Boston: Boston, MA, USA, 2019; Available online: https://www.bostonfed.org/publications/new-england-public-policy-center-regional-briefs/2019 /aging-and-declining-populations-in-northern-new-england.aspx (accessed on 19 March 2020).

138. Cromartie, J.; USDA ERS. Shifting Geography of Population; USDA ERS: Washington, DC, USA, 2019. 
139. Danielson, D. Movement Continues from State's Smaller Counties to Large Metro Areas. Radio Iowa. 2019. Available online: https://www.radioiowa.com/2019/04/18/movement-continues-from-states-smaller-counties -to-large-metro-areas/ (accessed on 19 March 2020).

140. Economic Innovation Group. The New Map of Economic Growth and Recovery. 2016. Available online: https://eig.org/wp-content/uploads/2016/05/recoverygrowthreport.pdf (accessed on 19 March 2020).

141. Economic Innovation Group. 2018 Distressed Communities Index. 2018. Available online: https://eig.org/dc i/2018-dci-map-national-zip-code-map (accessed on 5 January 2020).

142. Vallenatos, E. America: Becoming a Land Without Farmers. Available online: https://www.independentsci encenews.org/environment/America-becoming-a-land-without-farmers/ (accessed on 20 December 2019).

143. Lobao, J.M.; Schulman, M.D.; Swanson, L.E. Still Going: Recent Debates on the Goldschmidt Hypothesis. Rural Sociol. 1993, 58, 277-288. [CrossRef]

144. Parkins, J.R. Industrial Agriculture and Community Outcomes: A Preliminary Study of Goldschmidt's Hypothesis in Rural Canada; Staff Paper Series 206563; University of Alberta. Department of Resource Economics and Environmental Sociology: Edmonton, AB, Canada, 2015.

145. Haslam, G.W. The Other California. The Great Central Valley in Life and Letters; Joshua Odell Editions and Capra Press: Santa Barbara, CA, USA, 1990.

146. Schneider, M.U.S. Had Its Slowest Population Growth Rate in A Century. Available online: https://www.pbs. org/newshour/nation/u-s-had-its-slowest-growth-rate-in-a-century (accessed on 11 January 2020).

147. Prior, J.C. Landscape Features of Iowa. Available online: https://www.iihr.uiowa.edu/igs/landscape-featuresof-Iowa/ (accessed on 20 December 2019).

148. Hardy, K. "No Hard Feelings:" Tyson Finally Agrees to Leave Empty Factor as New Meat Processor Opens Shop. Des Moines Register, 19 September 2018. Available online: https://www.desmoinesregister.com/story/money/bu siness/2018/09/19/tyson-foods-cherokee-iowa-plant-iowa-food-group-moves-justin-robinson-pork-beefchicken-processing/1356962002/(accessed on 19 March 2020).

149. Peikes, K. Lopez Foods Buys Idled Northwest Iowa Meat Processing Plant; Radio Iowa: Des Moines, IA, USA, 2019; Available online: https://www.radioiowa.com/2019/10/22/lopez-foods-buys-idled-northwest-iowa-m eat-processing-plant/ (accessed on 19 March 2020).

150. Hardy, K. Farm Country Feeds America, But Just Try Buying Groceries There. New York Times, 5 November 2019. Available online: https://www.nytimes.com/2019/11/05/us/rural-farm-market.html (accessed on 19 March 2020).

151. Hardy, K.; Chen, Y. This Map Shows the Stark Reality of Rural Iowa's Population Loss. Des Moines Register, 12 December 2018. Available online: https://www.desmoinesregister.com/story/news/2018/05/29/map-shows-starkreality-iowa-rural-population-loss-depopulation-metro-urban/652175002/ (accessed on 19 March 2020).

152. Hertz, T.; Kusmin, L.; Marre, A.; Parker, T. Rural Employment Trends in Recession and Recovery, USDA Economic Research Service, 2014, No. 172, August. Available online: https://www.ers.usda.gov/webdocs/p ublications/45258/48731_err172.pdf?v=0 (accessed on 1 January 2020).

153. Munson, K. Where Have All of Iowa's Children Gone? Des Moines Register, 27 December 2017. Available online: https://www.desmoinesregister.com/story/news/local/columnists/kyle-munson/2017/12/27/childle ss-small-towns-iowa-struggle-aging-population/909256001/ (accessed on 19 March 2020).

154. Fikri, K.; Lettieri, J. From Great Recession to Great Reshuffling: Charting a Decade of Change Across American Communities. 2018, p. 27. Available online: https://eig.org/wp-content/uploads/2018/10/2018-DCI.pdf (accessed on 19 March 2020).

155. Henderson, J. Prospects for a Rural Recovery. Ag Decis. Maker Newsl. 2009, 14, 5. Available online: https://lib.dr.iastate.edu/agdm/vol14/iss2/1 (accessed on 19 March 2020).

156. Robinson, W. Abandoned New England: Its Hidden Ruins and Where to Find Them; New York Graphic Society: Boston, MA, USA, 1976.

157. Thorson, R.M. Stone by Stone: The Magnificent History of New England Stone Walls; Walker and Company: New York, NY, USA, 2002.

158. US Census Bureau. 2010 Census of Population and Housing, Summary Population and Housing Characteristics, CPH-1-21, Maine; US GPO: Washington, DC, USA, 2012.

159. Cities in Woodbury County Past and Present. Available online: https://siouxcityjournal.com/special-section /local/cities-in-woodbury-county-past-and-present/article_3fee7c62-0f0a-567c-b534-eb2d59c3c30c.html (accessed on 6 January 2020). 
160. Butz, D. A Fire Breaks Out at Correctionville Grocery Store. Sioux City Journal, 30 September 2009. Available online: https://siouxcityjournal.com/news/local/state-and-regional/fire-breaks-out-at-correctionville-groc ery-store/article_44fddfab-07de-5956-b497-c81ba93e11be.html (accessed on 19 March 2020).

161. Dockter, M. Correctionville's Mercantile Grocery Store Goes on the Auction Block Monday. Sioux City Journal, 10 April 2019. Available online: https://siouxcityjournal.com/business/local/correctionville-s-mercantile-gro cery-store-goes-on-the-auction-block/article_7c9ec747-dd08-5911-963c-c9ce1dcbaefa.html (accessed on 19 March 2020).

162. Gallagher, T. Walls Tumble as Old Opera House Crumbles. Sioux City Journal, 29 December 2010. Available online: https://siouxcityjournal.com/news/local/a1/walls-tumble-as-old-opera-house-crumbles/article_4c 094bf4-eb56-5299-9a4e-460235e6605d.html (accessed on 19 March 2020).

163. Gallagher, T. Back in Business: Grocery Store Beats ion the Heart of Correctionville, Iowa. Sioux City Journal, 10 January 2013. Available online: https://siouxcityjournal.com/news/gallagher-grocery-store-beatsin-the-heart-of-correctionville-iowa/article_64ef71a2-235a-561c-896f-02453d51a339.html (accessed on 19 March 2020).

164. Aubrey, A. Dollar Stores and Food Deserts. Available online: https://www.cbsnews.com/news/dollarstores-and-food-deserts-the-latest-struggle-between-main-street-and-corporate-america/ (accessed on 4 January 2020).

165. Center for Engagement and Community. Kansas State University. Rural Grocery Institute. Available online: https://www.ruralagency.org (accessed on 3 January 2020).

166. Farzan, A.N. When a Deep Red Town's Only Grocery Closed, City Hall Opened Its Own Store. Just Don't Call It 'Socialism'. Washington Post, 22 November 2019. Available online: https://www.washingtonpost.com /nation/2019/11/22/baldwin-florida-food-desert-city-owned-grocery-store/ (accessed on 19 March 2020).

167. Morris, F. How Dollar General Is Transforming Rural America. NPR, 11 December 2017. Available online: https://www.npr.org/2017/12/11/569815331/loving-and-hating-dollar-general-in-rural-america (accessed on 19 March 2020).

168. Young, R. 2019 When Grocery Stores Close, Rural Food Deserts Turn to City-Owned Cooperatives. Available online: https://www.wbur.org/hereandnow/2019/11/25/city-owned-grocery-stores (accessed on 4 January 2020).

169. Dollar General. Available online: https://aboutus.dollargeneral.com/ (accessed on 4 January 2020).

170. Gallagher, T. A "Stirring" Rises from Ashes in Downtown Correctionville. Sioux City Journal, 18 January 2019. Available online: https://siouxcityjournal.com/news/local/columnists/gallagher/gallagher-a-stirring-ri ses-from-ashes-in-downtown-correctionville/article_ac9988ca-ea32-5ab8-a5d9-ad90e79bc9dc.html (accessed on 19 March 2020).

171. McGreal, C. Where Even Walmart Won't Go: How Dollar General Took Over Rural America. The Guardian, 13 August 2018. Available online: https://www.theguardian.com/business/2018/aug/13/dollar-general-walm art-buhler-haven-kansas (accessed on 19 March 2020).

172. Miranda, L. Thousands of Retailers Are Closing-But Dollar General is Opening Almost 20 Stores a Week. Available online: https://www.nbcnews.com/business/consumer/thousands-retail-stores-are-closing-so-how -dollar-General-general-opening-n1095791 (accessed on 4 January 2020).

173. Romell, R. Dollar General's Aggressive Expansion into Small Wisconsin Towns Has Hurt Locally Owned Grocery Stores. Milwaukee Journal Sentinel, 23 May 2019. Available online: https://www.jsonline.com/story/money/busin ess/retail/2019/05/23/dollar-general-growth-hits-grocers-wisconsins-small-towns/3620981002/ (accessed on 19 March 2020).

174. Gallagher, T. Are Anthon Fixture's Days Numbered? Sioux City Journal, 28 November 2011. Available online: https://siouxcityjournal.com/news/local/gallagher-are-anthon-fixture-s-days-numbered/article_6c1 b5f89-8ad6-5432-a199-a81c62e2c309.html (accessed on 19 March 2020).

175. Gallagher, T. Check Out Anthon's Market. Sioux City Journal, 29 May 2012. Available online: https://siouxcityjournal.com/lifestyles/check-out-anthon-s-market/article_ec3b68a6-436f-593d-84d 3-c4976a9ec991.html (accessed on 19 March 2020). 
176. Dockter, M.; Iowa Food Group Suspends Production at Cherokee Plan to Raise More Capital. Sioux City Meatpacking History. Sioux City Journal, 27 October 2019. Available online: https://siouxcityjournal.com/news/local/iowa-food-group-suspends-production-at-cherokee-plant-to -raise/article_fa503de2-4ea0-5376-abed-821a897d8851.html (accessed on 19 March 2020).

177. Struck, P.; Iowa Food Group Shuts Down. Major Investor Pulls Plug. Employees Sent Home. Cherokee Chronicle Times, 10 April 2019. Available online: https://www.chronicletimes.com/story/2600649.html (accessed on 19 March 2020).

178. Dockter, M. Former Iowa Food Group Plant in Cherokee Gets New Owner. Sioux City Journal, 27 October 2019. Available online: https://siouxcityjournal.com/business/local/former-iowa-food-group-plant-in-cherok ee-gets-new-owner/article_c046ce86-d45c-532f-84bb-3f71e9b8b96a.html (accessed on 19 March 2020).

179. Dreeszen, D. Ex-Tyson Site in Cherokee to Reopen as Meat Processing Plant. Sioux City Journal, 19 September 2018. Available online: https://siouxcityjournal.com/ex-tyson-site-in-cherokee-to-reopen-as-meat-processin g/article_2b0c9dba-fc8d-5e82-8f30-913c48c53c86.html (accessed on 19 March 2020).

180. Taylor, A. Cherokee Welcomes Iowa Food Group. Available online: https://siouxlandnews.com/news/local/c herokee-welcomes-iowa-food-group (accessed on 20 December 2019).

181. Wauran, J. Iowa Workshop Development Holding Unemployment Meeting for Employees of Iowa Food Group. KMEG, 9 April 2019. Available online: https://siouxlandnews.com/news/local/iowa-food-group-ann ounces-pause-in-production (accessed on 19 March 2020).

182. MercyOne Siouxland Medical Center. Available online: https://www.mercyone.org/siouxland/about-us/ (accessed on 7 January 2020).

183. MercyOne Supported by CHI \& Trinity Health. Available online: https://www.mercyone.org/about-us/nati onal-systems (accessed on 7 January 2020).

184. Mahoney, M. Willoway Complex Units Ready for Renters. The N'West Iowa REVIEW, 23 April 2018. Available online: https://www.nwestiowa.com/news/willoway-complex-units-ready-for-renters/article_df1c7216-4 73b-11e8-ba00-43ca5255b11e.html (accessed on 19 March 2020).

185. Butz, D. Couple Transforms School into Stained Glass Studio, Home. Sioux City Journal, 13 November 2014.

186. Center for Rural Affairs. Iowa Wind Energy Tax Revenue. Available online: https://www.cfra.org/publicati ons/WindEnergyTaxRevenue (accessed on 19 March 2020).

187. Eller, D.; Hardy, K. Is Wind Power Saving Rural Iowa or Wrecking It? Des Moines Register, 20 April 2017.

188. Hartland (Maine) Sesquicentennial Steering Committee. 1820-Hartland, Maine-1970; Town of Hartland, Maine: Hartland, ME, USA, 1970.

189. Woolen Mills and Tannery: Including Linn Woolen Mill, American Woolen Mill, Hartland Mills, Inc and Hartland Company. Hartland Historical Society, n.d. Available online: https://www.hartlandmainehistorica lsociety.org/woolen-mill--tannery.html (accessed on 1 January 2020).

190. Ellison, J. Why Isn't Starks More Excited about Legal Pot? Down East: The Magazine of Maine, October 2019; 76-86. Available online: https://downeast.com/our-towns/starks-maine/ (accessed on 19 March 2020).

191. Philo, C. Neglected Rural Geographies: A review. J. Rural Stud. 1992, 8, 193-207. [CrossRef]

192. Cloke, P. Country backwater to virtual village: Geographical Turns; Retrospect and prospect. J. Rural Stud. 1997, 20, 95-111.

193. Liepins, R. Exploring rurality through 'community;' discourses and spaces sharing Australian and New Zealand rural communities. J. Rural Stud. 2000, 16, 325-341. [CrossRef]

194. Liepins, R. New energies for an old idea: Reworking approaches to 'community' in contemporary rural societies. J. Rural Stud. 2000, 16, 23-35. [CrossRef]

195. Munton, R. (Ed.) The Rural. Critical Essays in Rural Geography; Ashgate: Aldershot, UK, 2008.

(C) 2020 by the authors. Licensee MDPI, Basel, Switzerland. This article is an open access article distributed under the terms and conditions of the Creative Commons Attribution (CC BY) license (http://creativecommons.org/licenses/by/4.0/). 